\title{
Carbon Sequestration in Soil Aggregates under Different Cropping Patterns of Bangladesh
}

\author{
Md. Sadiqul Amin'1, Md. Zulfikar Khan1,2*, Tutul Laskar ${ }^{1}$, Sheikh Mohammad Fazle Rabbi ${ }^{3}$ \\ ${ }^{1}$ Soil, Water and Environment Discipline, Khulna University, Khulna, Bangladesh \\ ${ }^{2}$ Forestry and Environmental Science, University of Tuscia, Viterbo, Italy \\ ${ }^{3}$ School of Life and Environmental Sciences, University of Sydney, Sydney, Australia \\ Email: *Zulfikar.ku11@gmail.com
}

How to cite this paper: Amin, Md.S., Khan, Md.Z., Laskar, T. and Rabbi, S.M.F. (2020) Carbon Sequestration in Soil Aggregates under Different Cropping Patterns of Bangladesh. Open Journal of Soil Science, 10, 459-485.

https://doi.org/10.4236/ojss.2020.1010024

Received: August 18, 2020

Accepted: October 17, 2020

Published: October 20, 2020

Copyright (c) 2020 by author(s) and Scientific Research Publishing Inc. This work is licensed under the Creative Commons Attribution International License (CC BY 4.0).

http://creativecommons.org/licenses/by/4.0/

\section{Open Access}

\begin{abstract}
Land use change and cropping patterns are important factors for controlling carbon sequestration in soils and they may also change the relative importance of different mechanisms of soil organic matter stabilization. The study was conducted to investigate the state of carbon sequestration in soil aggregates under different cropping patterns of Khulna, Jessore and Chapainawabganj districts in Bangladesh. Thirty-six soil samples were collected from (0 - $100 \mathrm{~cm}$ depth) above mentioned regions of three physiographic regions: Ganges Meander Floodplain, Ganges Tidal Floodplain and High Barind Tract. The texture of the samples varied within three soil texture groups, Silt Loam, Silty Clay Loam and Silty Clay. The highest NSI value (0.89) was found under Wheat-Fallow-T. Aman cropping pattern in Silty Clay soils (sample No 15) and lowest value (0.59) was found Vegetables/Mustard-Fallow-T. Aman cropping pattern in Silt Loam soils (sample No 17). The highest value (735.20 $\mathrm{mg} \cdot \mathrm{kg}^{-1}$ ) of active $\mathrm{C}$ was observed under Chickpea/mustard-T. Aman (Sample No 31) and the lowest value (619.23 $\mathrm{mg} \cdot \mathrm{kg}^{-1}$ ) was found in case of Wheat-Fallow-T. Aman cropping pattern (Sample No 30). The highest SOC stock (1.62 $\mathrm{Kg} \mathrm{C} \mathrm{m}^{-2}$ ) was found in Silty Clay Loam soil under Mungbean/Ash gourd-T. Aman cropping pattern (Sample no 4) and the lowest SOC stock (0.35 $\mathrm{Kg} \mathrm{C} \mathrm{m}{ }^{-2}$ ) was found in Silt Loam soil under Cauliflower/Pumkin/Spinach-T. Aman Cropping pattern (Sample No 2). Soil organic carbon associated with different size aggregates was the highest (3.14\%) under Mungbean/Ash gourd-T. Aman (Sample No 20) and was the lowest (0.36\%) under Cauliflower/Pumkin/Spinach-T. Aman cropping pattern (Sample No 2). Organic carbon content in aggregate size ranges > $2000 \mu \mathrm{m}$ (SOC1), $2000-250 \mu \mathrm{m}$ (SOC2), 250-53 $\mu \mathrm{m}$ (SOC3), and $<53 \mu \mathrm{m}$ (SOC4) varied from $0.36 \%-1.90 \%$, $0.52 \%-2.10 \%, 0.50 \%-2.60 \%$ and $0.50 \%-1.62 \%$, respectively. The percentages of SOC associated with $<53 \mu \mathrm{m}$ aggregates were higher than those of $>2000 \mu \mathrm{m}, 2000-250 \mu \mathrm{m}$ and $250-53 \mu \mathrm{m}$, aggregates. Significant positive
\end{abstract}


correlations were found between SOC stock and SOC1, SOC stock and SOC2, SOC stock and SOC3, SOC stock and SOC4.

\section{Keywords}

Carbon Sequestration, Carbon Stock, Soil Aggregate, Cropping Patterns, Climate Change

\section{Introduction}

Global warming is a major threat to the environment and soil management practices are now believed to contribute significantly to changing environmental conditions [1]. Attention has been increasingly paid to soil organic carbon (SOC) pool and its dynamics in land use changes concerning terrestrial ecosystem carbon sink and the uprising atmospheric carbon dioxide [2]. The global soil carbon (C) pool of 2500 gigatons (Gt) includes about $1550 \mathrm{Gt}$ of SOC and $950 \mathrm{Gt}$ of soil inorganic carbon (SIC). The soil C pool is 3.3 times the size of the atmospheric pool $(760 \mathrm{Gt}$ ) and 4.5 times the size of the biotic pool ( $560 \mathrm{Gt})$. The SOC pool to $1-\mathrm{m}$ depth ranges from 30 tons/ha in arid climates to 800 tons/ha in organic soils in cold regions, and a predominant range of 50 to 150 tons/ha. The SOC pool represents a dynamic equilibrium of gains and losses. Conversion of natural to agricultural ecosystems causes depletion of the SOC pool by as much as $60 \%$ in soils of temperate regions and $75 \%$ or more in cultivated soils of the tropics. Severe depletion of the SOC pool degrades soil quality, reduces biomass productivity, and adversely impacts water quality, and the depletion may be exacerbated by projected global warming [1]. Carbon stock occurring in the topsoil is the most important, because this is the portion more influenced by external environmental and human factors and therefore the mainly susceptible to mineralization or synthesis processes. On the contrary, in deep layers, soil organic carbon is more stable and less liable to transformation. Soil surface layers account for the main part of the soil carbon stocks: on average, the $47 \%$ of the carbon stored in soils is held in the first $30 \mathrm{~cm}$; about $2 / 3$ are stored within a depth of $50 \mathrm{~cm}$ and the $80 \%$ within one meter. Soil carbon storing capability depends on many factors, such as pedoclimatic conditions, crop management practices and the starting soil carbon levels and on the interactions among them.

Urgency of meeting increased demand for agricultural produce is rapidly degrading soil quality and exacerbating degradation. Most agricultural soils have low soil organic matter (SOM) reserves due to fertility-mining practices and widespread problem of soil degradation. This decline is also attributed to removal of crop residue, and changes in cropping systems etc. Crop yield and use efficiency of input are also adversely affected by low levels of SOC pool [3].

Land use practices that result in a net accumulation of SOM in the soil are said to be $\mathrm{C}$ sequestering because they result in a net removal of $\mathrm{C}$ from the at- 
mosphere [4]. Several studies in temperate and tropical regions reported that no-tillage practices substantially increase SOM storage and improve soil aggregation [5]. Soil aggregation can increase SOC storage by reducing loss by erosion and from mineralization. Soil organic matter can be physically protected from microbial mineralization through sorption to clay minerals and enclosure within soil aggregates [6]. Improvement in soil aggregation is an important factor influencing SOC sequestration in soils [7]. Soil aggregation is an important process of $\mathrm{C}$ sequestration and hence a useful strategy to mitigate the increase in concentration of atmospheric $\mathrm{CO}_{2}[8]$.

Tillage causes loss of soil organic matter through destruction of macro-aggregates and microbial mineralization of the physically protected SOM pool. Micro-aggregates and their associated SOC are stable to tillage, and this "passive or chemically protected" SOC pool represents the minimum level of SOC. Rice-wheat surface soils $(0-15$ or $0-20 \mathrm{~cm})$ from Bangladesh increase in $\mathrm{SOC}$ as their silt + clay fraction increases. This variability may reflect differences in manure use, years under cultivation, tillage, sampling depth or length of time that soils are flooded [9]. Significant amounts of OC will not accumulate in soils in these environments without the protective effects of interactions with mineral surfaces (as provided by silt/clay) and the formation of aggregates. Hopelass et al. [10] reported that there was a trend of increase in concentration of SOC with decreasing aggregate size, but significant differences in these parameters in different aggregate size fractions were found only in few cases. The SOC concentration was higher in $>0.25 \mathrm{~mm}$ than in $<0.25 \mathrm{~mm}$ aggregates. The $\mathrm{SOC}$ sequestration rate by judicious use of inorganic fertilizer was the greatest in the grain-meadow rotation, while that by application of FYM was the greatest in the all grain rotation. Shrestha et al. [8] studied water stability of soil aggregates (WSA) and SOC associated with aggregates and primary particles of cultivated and forest soils. They concluded that microaggregates $(<0.5 \mathrm{~mm})$ were abundant $(56 \%-63 \%)$ in cultivated soils but cultivated soils contained higher amounts of clay but less clay-associated SOC than forest soils.

Bangladesh is a tropical agrarian country with high population density and astounding food demand. Overexploitation of agricultural soils causes severe soil degradation in Bangladesh. Depletion of SOM is a widespread problem on croplands and grazing lands in the country. Most soils have low levels of SOC contents, ranging from 8 to $10 \mathrm{~g} / \mathrm{kg}$. Low external input of organic amendment causes depletion of SOC pool because nutrients harvested in agricultural products are not replaced, and are made available through mineralization of SOM. In some cases, soil is burnt to release nutrients contained in SOM. It is estimated that SOC loss due to agricultural activities in Bangladesh between 1967 and 1995 was $16.2 \mathrm{Mg} \mathrm{C} / \mathrm{ha}$, with a range of 3.8 to $30.5 \mathrm{Mg} \mathrm{C} / \mathrm{ha}$ [3]. To meet the increased food demand cropping intensity must be increased and cropping pattern should be changed. Rabbi et al. [11] reported that in silt loam soil highest percent \%SOM was estimated under Fallow-Fallow-T. Aman (2.90\%) and lowest under Vegetable-Sugarcane/Jute pattern $(0.86 \%)$. The soils under Vegetable, 
Vegetable-Vegetable, Fallow-Jute-T. Aman, Fallow-Aus-Vegetable and Rabi-Jute-T. Aman patterns had relatively lower \%SOM than other patterns. The \%SOM under Sesame-Fallow-T. Aman pattern varied in different agricultural fields and it was $1.22 \%$ to $2.11 \%$. In loam soils highest \%SOM was obtained under Rabi-Jute-Turmeric (1.54\%) and lowest under Boro-Fallow-T. Aman pattern (0.55\%). Soils under Fallow-Fallow-T. Aman, Boro-T. Aman/Fish and Fallow-Jute-T. Aman patterns also had higher \%SOM whereas Soils under Boro-Shrimp had lower \%SOM in loam soil. The \%SOM in silty clay loam soil under Boro-Fallow-T. Aman varied between $0.96 \%$ and $1.54 \%$. The highest \%SOM $(2.05 \%)$ was obtained under Wheat-Jute-T. Aman pattern in silty clay soil and lowest $(0.76 \%)$ in clay loam soil under Vegetable-Aus/Jute/Vegetable pattern. Soils under Fallow-Fallow-T. Aman in silt loam soil had higher \%SOM than in loam soil under same pattern. The higher \%SOM was obtained under Boro-Fallow-T. Aman pattern in silty clay loam soil than loam soils. It was reported that micro-aggregation of soils was also influenced by cropping patterns of the studied agricultural fields. The aggregate stability of soils of Ganges Floodplain is closely related with soil organic matter [12]. Therefore, the objectives of the research project were to evaluate the state of SOC sequestration in the agricultural soils under different cropping patterns and estimate the carbon stock of soils.

\section{Methods and Materials}

The study was conducted on agricultural soils of Jessore Sadar and Bagherpara Upazila under Jessore District, Phultala Upazila under Khulna District and the Nachole Upazila under Chapainawabganj District (Figures 1-5). General information's of sampling sites are given in Table 1. Thirty-six soil samples (Core and Bulk sample) were collected from $0-100 \mathrm{~cm}$ soil depth and all soil samples were kept in sealed plastic bags. Marking and labelling was performed with a detailed description of the selected sampling site on both the soil-plastic bags, and preserved in plastic bags until arrival at the laboratory for sample preparation. Then samples were air dried by spreading the soils on separate sheet of papers. After drying in air, the larger aggregates were broken through gentle crushing with a wooden hammer. A portion of the crushed soils was passed through by using different size sieves. The ranges were $>2000 \mu \mathrm{m}, 2000-250$ $\mu \mathrm{m}, 250-53 \mu \mathrm{m}$ and $<53 \mu \mathrm{m}$ aggregate size range. The sieved soils were then preserved in plastic bags and labeled properly. These samples were later used for various chemical analyses.

\subsection{Soil Physical Properties}

The particle size analyses of the soils were carried out by combination of sieving and hydrometer method as described by Gee and Bauder [13]. Textural classes were determined by using Marshall's Triangular Coordinator system. Bulk density of soil was determined by core method as described by Blake and Hartge 
Table 1. Sampling locations, cropping patterns with physiography.

\begin{tabular}{|c|c|c|c|c|}
\hline Sample No & Physiography & Location & Land use & Comments \\
\hline 1 & & Village: Shabati & Boro-Fallow-T. Aman & \\
\hline 2 & & $\begin{array}{l}\text { Union: Ramnagar } \\
\text { Upazila: Jessore }\end{array}$ & Cauliflower/Pumkin/Spinach-T. Aman & \\
\hline 3 & & & Lentil/Onion-Jute-T. Aman & \\
\hline 4 & & & Vegetables/Mustard-Fallow-T. Aman & \\
\hline 5 & & Village: Bahadurpur & Brinjal/Mustard-Fallow-T. Aman & \\
\hline 6 & & Union: Noapara & Mahogany garden & \\
\hline 7 & & Upazila: Jessore & Mustard-Fallow-T. Aman & \\
\hline 8 & & & Wheat-Fallow-T. Aman & \\
\hline 9 & & & Vegetables/Mustard-Fallow-T. Aman & \\
\hline 10 & $\begin{array}{l}\text { Ganges Meander } \\
\text { Floodplain }\end{array}$ & $\begin{array}{l}\text { Village: Nongorpur } \\
\text { Union: Esaali } \\
\text { Upazila: Jessore }\end{array}$ & Brinjal/Mustard-Fallow-T. Aman & \\
\hline 11 & & $\begin{array}{l}\text { Village: Sadipur } \\
\text { Union: Bondhobila } \\
\text { Upazila: Bagharpara }\end{array}$ & Rice-Colocasia & \\
\hline 12 & & Village: Gaithghat & Bean-Fallow-T. Aman & \\
\hline 13 & & Union: Bondhobila & Lentil-Fallow-T. Aman & \\
\hline 14 & & Upazila: Bagharpara & Khesari-Fallow-T. Aman & \\
\hline 15 & & $\begin{array}{l}\text { Village: Jugni pasa } \\
\text { Union: Bejerdanga }\end{array}$ & Wheat-Fallow-T. Aman & \\
\hline 16 & & Upazilla: Fultala & Wheat-Dhaincha-T. Aman & \\
\hline 17 & \multirow{11}{*}{$\begin{array}{l}\text { Ganges Tidal } \\
\text { Floodplain }\end{array}$} & Village-Hogladanga & Vegetables/Mustard-Fallow-T. Aman & \multirow{6}{*}{$\begin{array}{c}\text { Ranisalute, Jotubalam, Banshful balam } \\
\text { (16 - } 18 \text { maunds/50 decimal) } \\
\text { Sesame: } 5 \text { - } 6 \text { maunds/50 decimal })\end{array}$} \\
\hline 18 & & Union-Bansbari & Sesame-T. Aman & \\
\hline 19 & & Upazila-Batiaghata & Boro-Vegetables-T. Aman & \\
\hline 20 & & Village-Joykhali & Mungbean/Ash gourd-T. Aman & \\
\hline 21 & & Union-Jolma & Ridge gourd/Ash gourd-T. Aman & \\
\hline 22 & & Upazila-Batiaghata & Sesame-T. Aman & \\
\hline 23 & & & Water melon-T. Aman & \multirow{5}{*}{ Greengram: 2.5 maunds/50 decimal } \\
\hline 24 & & & Rabi vegetables-T. Aman & \\
\hline 26 & & $\begin{array}{l}\text { Village-Ghola } \\
\text { Union-Jolma } \\
\text { Upazila-Batiaghata }\end{array}$ & $\begin{array}{l}\text { Sweet gourd-T. Aman } \\
\text { Sesame-Fallow-T. Aman }\end{array}$ & \\
\hline 27 & & & Greengram-T. Aman & \\
\hline 28 & & & Mungbean/Ridge gourd-T. Aman & \\
\hline 29 & \multirow{8}{*}{ High Barind Tract } & & Boro-Aus-T. Aman & \multirow{8}{*}{$\begin{array}{l}\text { Boro: BR-28 ( } 15 \text { - } 18 \text { maunds } / 33 \text { decimal), } \\
\text { Aus: Jirashail ( } 15 \text { - } 18 \text { maunds } / 33 \text { decimal) } \\
\text { Pariza ( } 12 \text { - } 15 \text { maunds } / 33 \text { decimal) } \\
\text { T Aman: Swarna ( } 16 \text { maunds } / 33 \text { decimal) } \\
\text { Wheat: } 4 \text { - } 5 \text { maunds } / 33 \text { decimal } \\
\text { Mustard: } 3 \text { maunds } / 33 \text { decimal) }\end{array}$} \\
\hline 30 & & & Wheat-Fallow-T. Aman & \\
\hline 31 & & & Chickpea/mustard-T. Aman & \\
\hline 32 & & $\begin{array}{c}\text { Village-Sobdolpur } \\
\text { Union-Kosba }\end{array}$ & Chickpea + Linseed-T. Aman & \\
\hline 33 & & Upazila-Nachol & Mustard-Fallow-T. Aman & \\
\hline 34 & & & Boro-Aus-T. Aman & \\
\hline 35 & & & Mango Garden & \\
\hline 36 & & & Mustard/coriander-T. Aman & \\
\hline
\end{tabular}




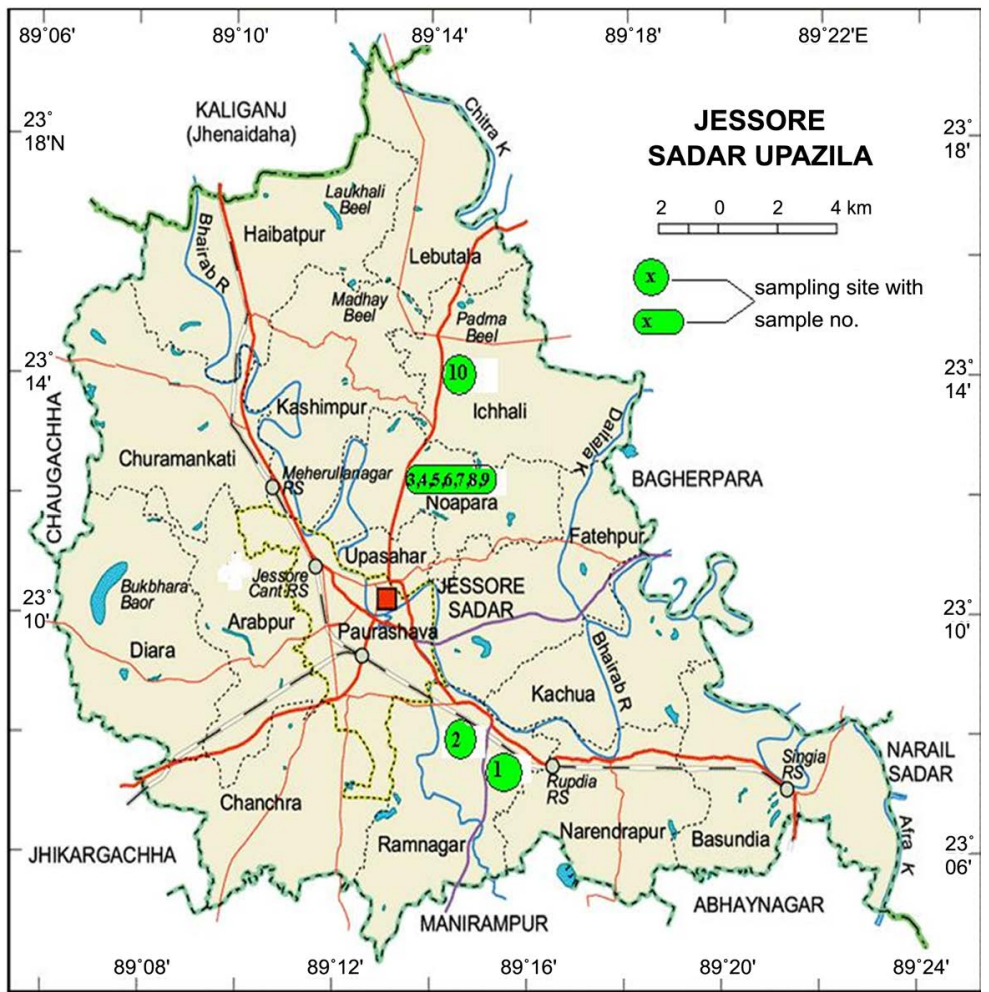

Figure 1. Sampling sites at Jessore sadar.

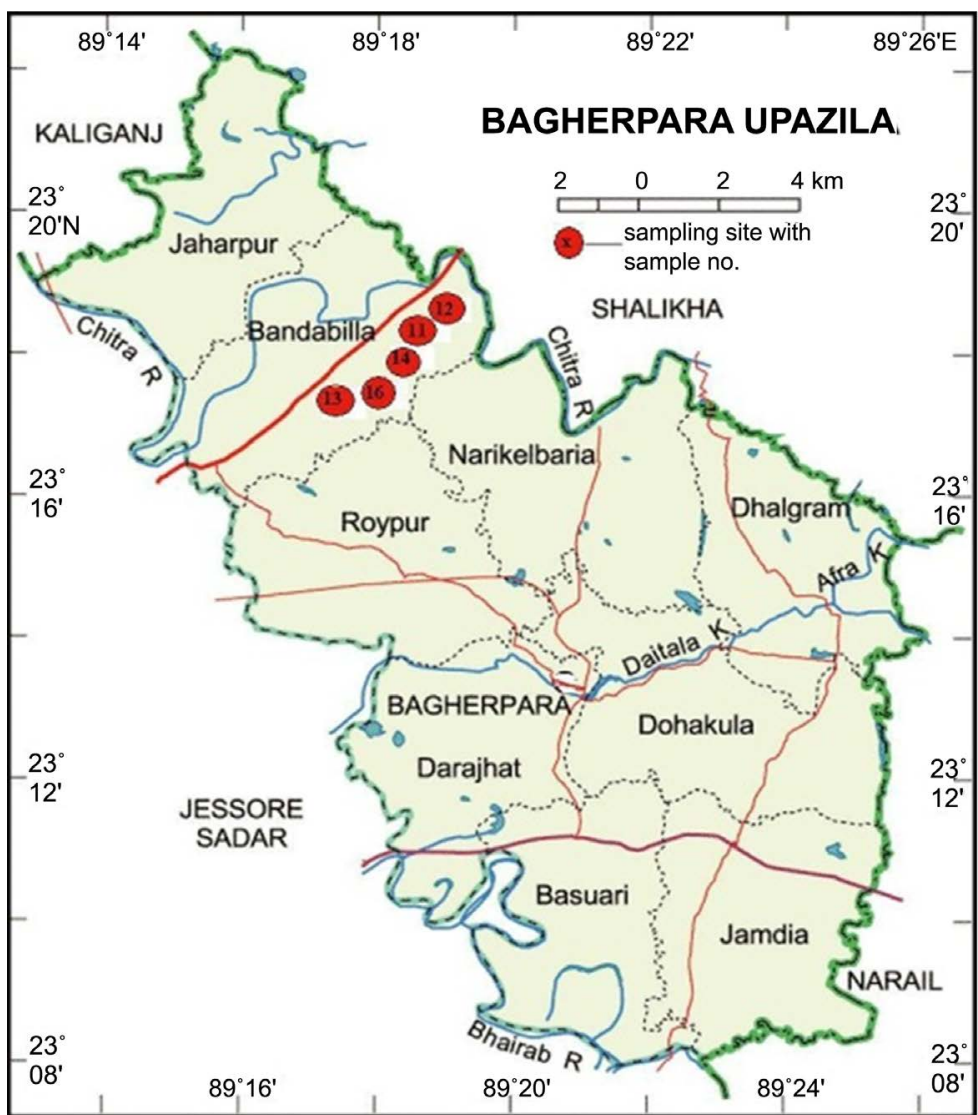

Figure 2. Sampling sites at Bagherpara. 


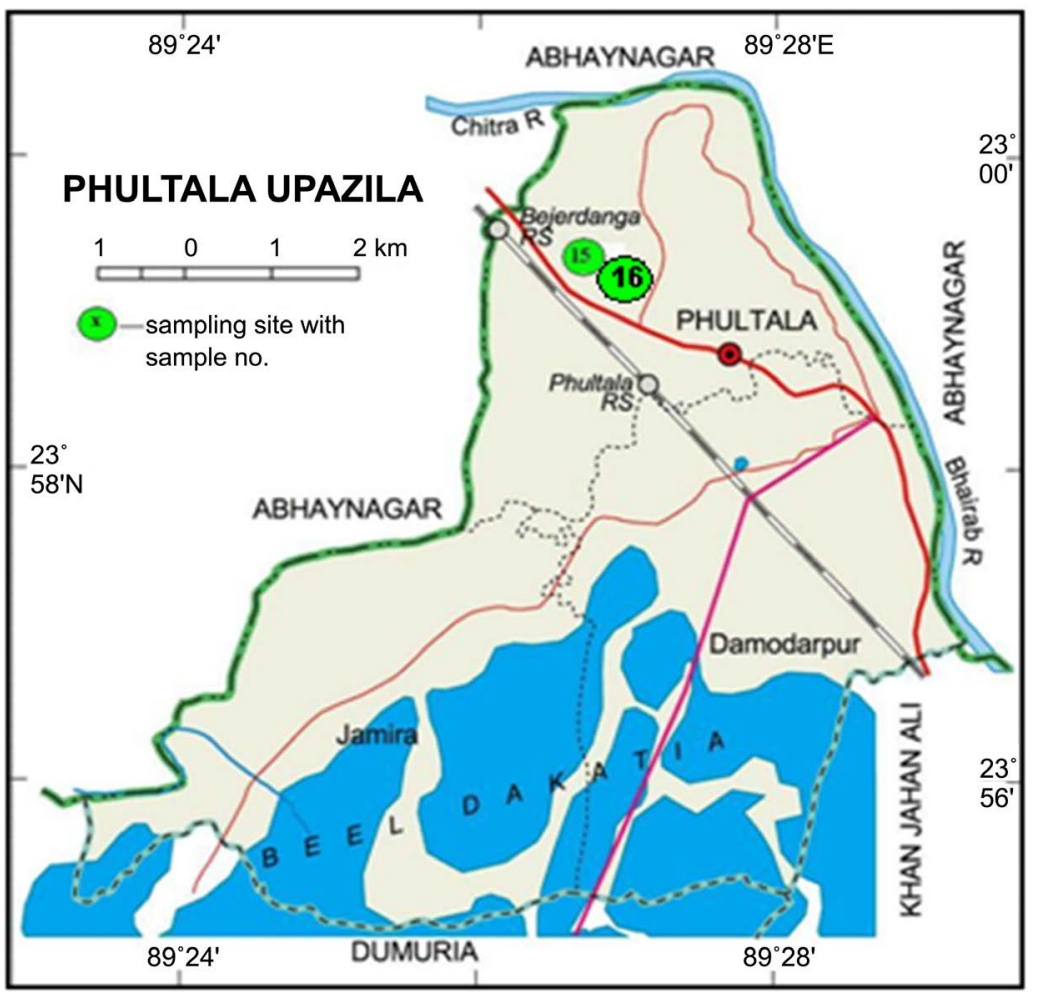

Figure 3. Sampling sites at Phultala.

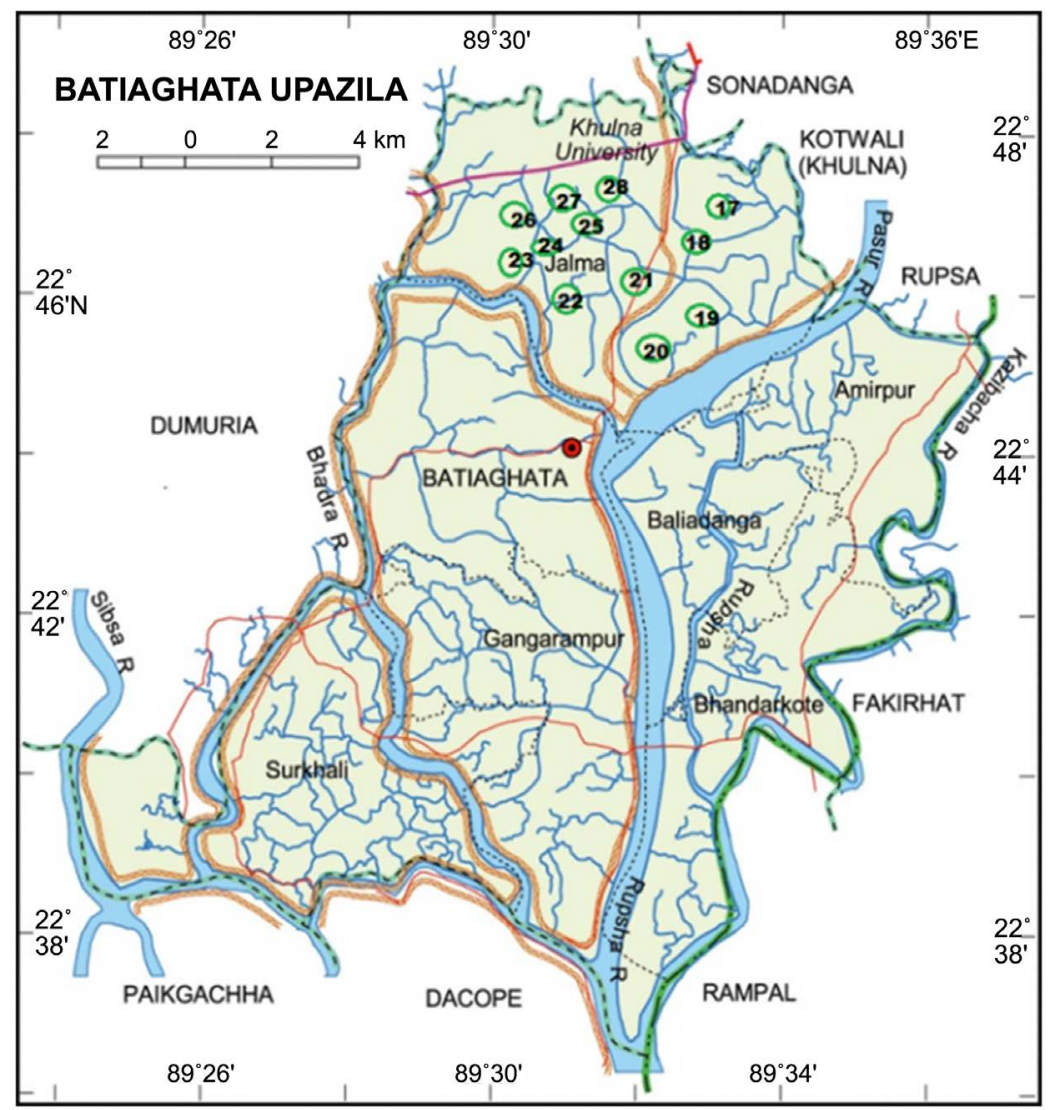

Figure 4. Sampling sites at Batiaghata upazila. 


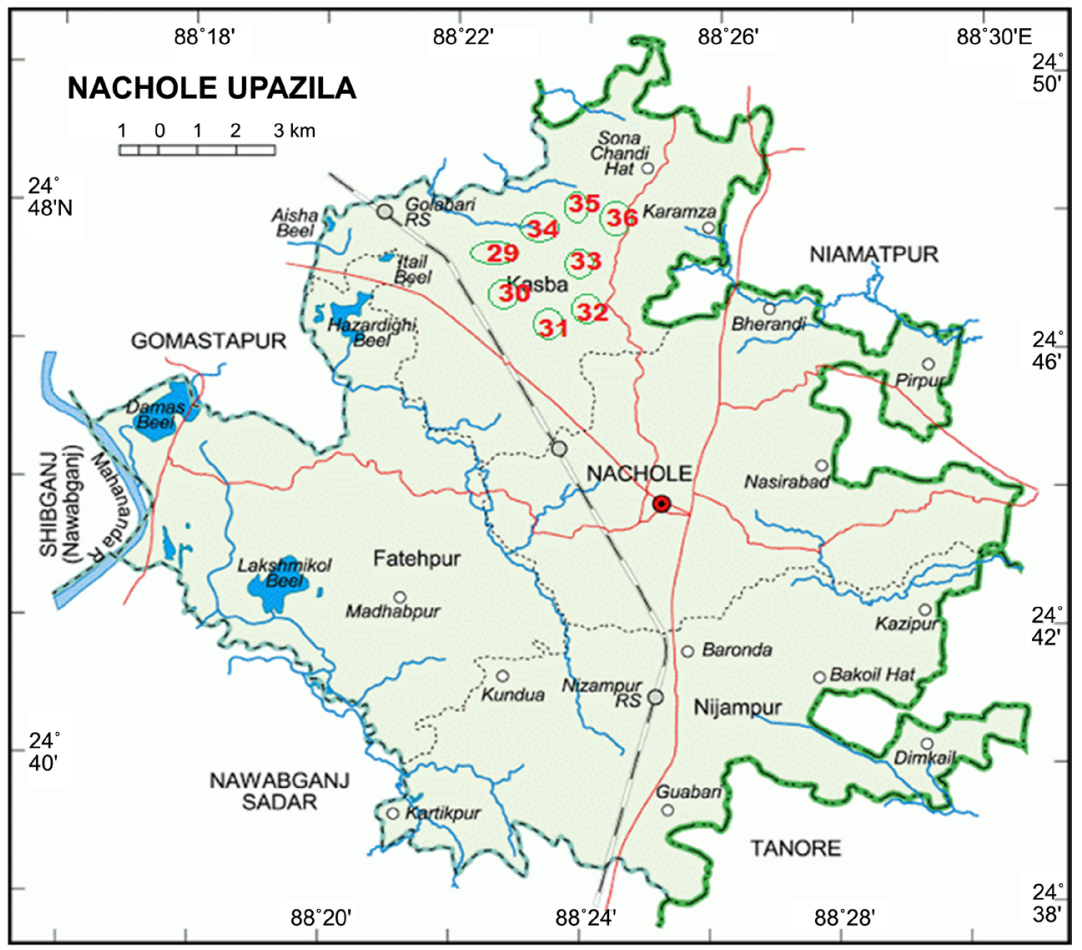

Figure 5. Sampling sites at Nachol upazila.

[14]. Particle density was determined by pycnometer meter as described by Blake and Hartge [14] and total porosity was calculated from bulk and particle density.

\section{Aggregate Stability (Normalized Stability Index) by Wet Sieving of the Aggregates}

The stability of aggregates was determined by the method as described by Six et al. [15]. For the determination of aggregate stability soil samples were air dried and crushed by a wooden hammer. The crushed soils were then sieved through 8 $\mathrm{mm}$ sieve. The air-dried soils that were passed through $8 \mathrm{~mm}$ sieve but retained on $2 \mathrm{~mm}$ sieve divided into $8-2 \mathrm{~mm}, 2-0.25 \mathrm{~mm}$ and $0.25-0.05 \mathrm{~mm}$ size fractions by hand sieving. For wet sieving with slaking pretreatment 10 grams air dried samples from each aggregate size fraction were submerged for 5 minutes on the top of smaller sieve of each size range prior to sieving. Soils were separated manually by moving the sieve $3 \mathrm{~cm}$ up and down under water with 50 repetitions during a period of 2 minutes. This manual separation technique was repeated for each size fractions. For wet sieving with wetted pretreatment the air-dried samples were adjusted to field capacity by soaking with water for overnight before submerging in water. The soils were then sieved for 2 minutes by the method as stated before. The amount of aggregates retained after sieving was oven dried at $105^{\circ} \mathrm{C}$ for 24 hours and then weighed. The number of primary particles retained on the sieves during wet sieving was determined by sieving after dispersing the soils with $5 \%$ sodium hexametaphosphate. The weight of primary particles was recorded after oven drying at $105^{\circ} \mathrm{C}$ for 24 hours.

The normalized stability index (NSI) of aggregates was calculated by the fol- 
lowing [5].

$$
\mathrm{NSI}=1-\left[\mathrm{DL} / \mathrm{DL}_{(\max )}\right]
$$

The whole soil disruption level (DL) was calculated as:

$$
\mathrm{DL}=1 / n \sum_{i}^{n}[(n+1)-i] \times \mathrm{DLS}_{i}
$$

where, $n=$ number of aggregate size classes.

$i=1$ for the smallest size class.

The disruption level of a size class upon slaking $\left(\mathrm{DLS}_{i}\right)$ was calculated by the following formula:

$$
\operatorname{DLS}_{i}=\frac{\left[\left\{\left(P_{i o}-S_{i o}\right)-\left(P_{i}-S_{i}\right)\right\}+\left|\left(P_{i o}-S_{i o}\right)-\left(P_{i}-S_{i}\right)\right|\right]}{2} \times \frac{1}{\left[P_{i o}-S_{i o}\right]}
$$

where,

$\mathrm{DLS}_{i}=$ disruption level for each size class $i ; P_{i o}=$ proportion of total sample weight in size class $i$ before disruption (i.e., rewetted); $P_{i}=$ proportion of total sample weight in size class $i$ after disruption (i.e., slaked); $S_{i o}=$ proportion of sand with size $i$ in aggregates of size $i$ (=aggregate-sized sand) before disruption; $S_{i}=$ proportion of sand with size $i$ in aggregates of size $i$ in aggregates after disruption.

The whole soil $\mathrm{DL}_{(\max )}$ was calculated by the following formula:

$$
\mathrm{DL}_{(\max )}=1 / n \sum_{i}^{n}[(n+1)-i] \times \operatorname{DLS}_{i(\max )}
$$

The maximum disruption $\left[\mathrm{DLS}_{i(\max )}\right]$ was calculated with the following formula:

$$
\operatorname{DLS}_{i(\max )}=\frac{\left[\left(P_{i o}-P_{p}\right)+\left|\left(P_{i o}-P_{p}\right)\right|\right]}{2} \times \frac{1}{\left[P_{i o}-S_{i o}\right]}
$$

$P_{p}=$ primary sand particle content with the same size as the aggregates size class after complete disruption of the whole soil.

\subsection{Soil Chemical Properties}

The soil $\mathrm{pH}$ was measured with the help of a glass electrode $\mathrm{pH}$ meter using soil water suspension ratio of 1:2.5 as described by Jackson [16]. Electrical conductivity (EC) of soil was estimated by EC meter (Jackson EC meter). Maintain the ratio with of soil to water of 1:5 and the result was converted to the ratio of 1:1 (soil:water) as suggested by USDA [17]. The soil organic carbon was determined by wet oxidation method of Walkley and Black's method as described by Jackson [16]. The soil organic carbon associated with $>2000 \mu \mathrm{m}, 2000-250 \mu \mathrm{m}, 250-53$ $\mu \mathrm{m}$ and $<53 \mu \mathrm{m}$ aggregates was determined. Stock of soil organic carbon was evaluated by the method of Ellert et al. [18]. Active soil organic carbon was determined by the method as described by Weil et al. [19].

\subsection{Statistical Analyses}

Statistical analysis was performed by Microsoft Excel and SPSS window version 
17.0 (SPSS Inc., Chicago, USA) to test the difference between means and correlation (statistical significance) of individual treatments [20].

\section{Results and Discussion}

\subsection{Particle Size Distribution}

The term particle size distribution of a soil refers to the percentage distribution of various sized particles in a given volume of soils. Particle size distribution is one of the most stable soil characteristics, being little modified cultivation or other practices. Although the usefulness of particle size analysis in practical agriculture has sometimes questioned, its indirect benefits have been extensive.

Samples studied were different in both of texture and cropping pattern. The percentage of clay was the highest (48\%) under Rice-Colocasia cropping pattern at sampling spot 11 and was the lowest (15\%) under Vegetables/Mustard-Fallow-T. Aman cropping pattern. Silt was the highest (68\%) under Vegetables/Mustard-Fallow-T. Aman and the lowest (40\%) under Wheat-Dhaincha-T. Aman cropping pattern with a mean value of 55.14. The percentage of sand was the highest (23\%) under Mahogany garden and the lowest (7\%) under both Ridge Gourd/Ash gourd-T. Aman and Rabi vegetables-T. Aman cropping patterns with a mean value of 15.38 (Table 2).

Table 2. Physical properties of soil samples.

\begin{tabular}{|c|c|c|c|c|c|c|c|}
\hline $\begin{array}{l}\text { Sample } \\
\text { No }\end{array}$ & \%Sand & $\%$ Silt & \%Clay & Texture & $\begin{array}{c}\text { Bulk } \\
\text { density }(g / c c)\end{array}$ & $\begin{array}{c}\text { Particle } \\
\text { Density }(g / c c)\end{array}$ & Porosity \% \\
\hline 1 & 20 & 57 & 23 & Silt Loam & 1.20 & 2.48 & 51.70 \\
\hline 2 & 21 & 59 & 20 & Silt Loam & 1.18 & 2.50 & 52.98 \\
\hline 3 & 20 & 55 & 25 & Silt Loam & 1.23 & 2.44 & 49.77 \\
\hline 4 & 16 & 64 & 21 & Silt Loam & 1.51 & 2.51 & 39.95 \\
\hline 5 & 19 & 56 & 25 & Silt Loam & 1.22 & 2.51 & 51.33 \\
\hline 6 & 23 & 54 & 23 & Silt Loam & 1.48 & 2.49 & 40.38 \\
\hline 7 & 20 & 56 & 24 & Silt Loam & 1.31 & 2.50 & 47.52 \\
\hline 8 & 21 & 58 & 21 & Silt Loam & 1.55 & 2.48 & 37.49 \\
\hline 9 & 9 & 50 & 41 & Silty Clay & 1.37 & 2.45 & 43.96 \\
\hline 10 & 18 & 59 & 23 & Silt Loam & 1.34 & 2.44 & 45.15 \\
\hline 11 & 11 & 41 & 48 & Silty Clay & 1.54 & 2.51 & 38.78 \\
\hline 12 & 12 & 41 & 47 & Silty Clay & 1.40 & 2.50 & 44.07 \\
\hline 13 & 13 & 61 & 26 & Silty Clay & 1.32 & 2.49 & 47.12 \\
\hline 14 & 13 & 64 & 23 & Silty Clay & 1.25 & 2.47 & 49.19 \\
\hline 15 & 21 & 45 & 34 & Silty Clay & 1.48 & 2.48 & 40.42 \\
\hline 16 & 12 & 40 & 48 & Silty Clay & 1.54 & 2.45 & 37.32 \\
\hline 17 & 17 & 68 & 15 & Silt Loam & 1.52 & 2.59 & 41.30 \\
\hline 18 & 8 & 61 & 31 & Silty Clay Loam & 1.46 & 2.55 & 42.72 \\
\hline
\end{tabular}




\begin{tabular}{|c|c|c|c|c|c|c|c|}
\hline Contin & & & & & & & \\
\hline 19 & 10 & 65 & 25 & Silt Loam & 1.34 & 2.59 & 48.24 \\
\hline 20 & 12 & 49 & 39 & Silty Clay Loam & 1.4 & 2.47 & 43.41 \\
\hline 21 & 7 & 54 & 39 & Silty Clay Loam & 1.52 & 2.52 & 39.59 \\
\hline 22 & 12 & 57 & 31 & Silty Clay Loam & 1.3 & 2.49 & 47.74 \\
\hline 23 & 10 & 50 & 40 & Silty Clay & 1.26 & 2.48 & 49.24 \\
\hline 24 & 7 & 59 & 34 & Silty Clay Loam & 1.34 & 2.48 & 45.97 \\
\hline 25 & 10 & 55 & 35 & Silty Clay Loam & 1.29 & 2.49 & 48.19 \\
\hline 26 & 10 & 60 & 30 & Silty Clay Loam & 1.3 & 2.50 & 48.00 \\
\hline 27 & 10 & 59 & 31 & Silty Clay Loam & 1.63 & 2.52 & 35.37 \\
\hline 28 & 10 & 60 & 30 & Silty Clay Loam & 1.59 & 2.51 & 36.65 \\
\hline 29 & 21 & 59 & 20 & Silt Loam & 1.49 & 2.48 & 39.83 \\
\hline 30 & 22 & 55 & 23 & Silt Loam & 1.49 & 2.51 & 40.62 \\
\hline 31 & 20 & 49 & 31 & Silty Clay Loam & 1.65 & 2.44 & 32.48 \\
\hline 32 & 19 & 53 & 28 & Silty Clay Loam & 1.22 & 2.45 & 50.13 \\
\hline 33 & 20 & 53 & 27 & Silt Loam & 1.52 & 2.48 & 38.61 \\
\hline 34 & 20 & 55 & 25 & Silt Loam & 1.84 & 2.48 & 25.88 \\
\hline 35 & 15 & 55 & 30 & Silty Clay Loam & 1.33 & 2.46 & 45.95 \\
\hline 36 & 18 & 54 & 28 & Silty Clay Loam & 1.22 & 2.45 & 50.13 \\
\hline
\end{tabular}

The texture of the samples varied within three soil texture groups, Silt Loam, Silty Clay Loam and Silty Clay (Table 2). This result resembles to several findings by many other researchers. SRDI staff [21] found that on the young Ganges meander floodplain, soils of ridges and inter-ridges depressions are silt loam to silty clay; and on the old Ganges meander floodplain, soils of ridges and depressions are loamy to clay in texture. They found that most ridge soils in old Brahmaputra floodplain are silt loam to silty clay loam and in inter-ridge depressions they are mostly silty clay loam to silty clay subsoil. Joshua and Rahman [22] found that the soils of the Tista floodplain, in general, contained a high percentage of silt and this property appears to be characteristic for the floodplain.

\subsection{Bulk Density, Particle Density and Porosity}

Bulk density varied in the range of 1.18 to $1.84 \mathrm{~g} / \mathrm{cc}$ with mean value of $1.40 \mathrm{~g} / \mathrm{cc}$, particle density in the range of 2.44 to $2.59 \mathrm{gm} / \mathrm{cc}$, porosity in the range of $25.88 \%-52.98 \%$ in soil samples under different cropping patterns (Table 2). The variations in the particle density, bulk density and porosity values under different cropping patterns were significant $(p<0.01)$. To a remarkable degree, increased organic matter can counteract the ill effects of too much clay or too much sand. Increasing the SOM content usually increases total porosity and therefore decreases bulk density [23]. At very high levels of SOM, additional OM has little further effect on soil aggregation and influences bulk density mainly 
because of its low particle density [24].

\subsection{Normalized Stability Index (NSI)}

In this research we found that the NSI varied from 0.51 to 0.89 under different cropping patterns (Appendix Table A1). The highest NSI value was found under Wheat-Fallow-T. Aman cropping pattern in Silty clay soils (sample No 15) and lowest value was found Vegetables/Mustard-Fallow-T. Aman cropping pattern in Silt loam soils (sample No 17).

Normalized Stability Index (NSI) of Silt Loam soils under different cropping patterns are presented in Figure 6. In Silt Loam soils the highest NSI value (0.87) was found under Cauliflower/Pumkin/Spinach-T. Aman (Sample No 2) and the lowest value (0.51) was obtained under Vegetables/Mustard-Fallow-T. Aman cropping pattern (Sample No 17).

Normalized Stability Index of Silty Clay Loam soils under different cropping patterns are presented in Figure 7. In S Silty Clay Loam soils the highest NSI value (0.87) obtained under Chickpea/mustard-T. Aman (Sample No 31) and the lowest value (0.59) obtained under Vegetables/Mustard-Fallow-T. Aman cropping pattern (Sample No 24).

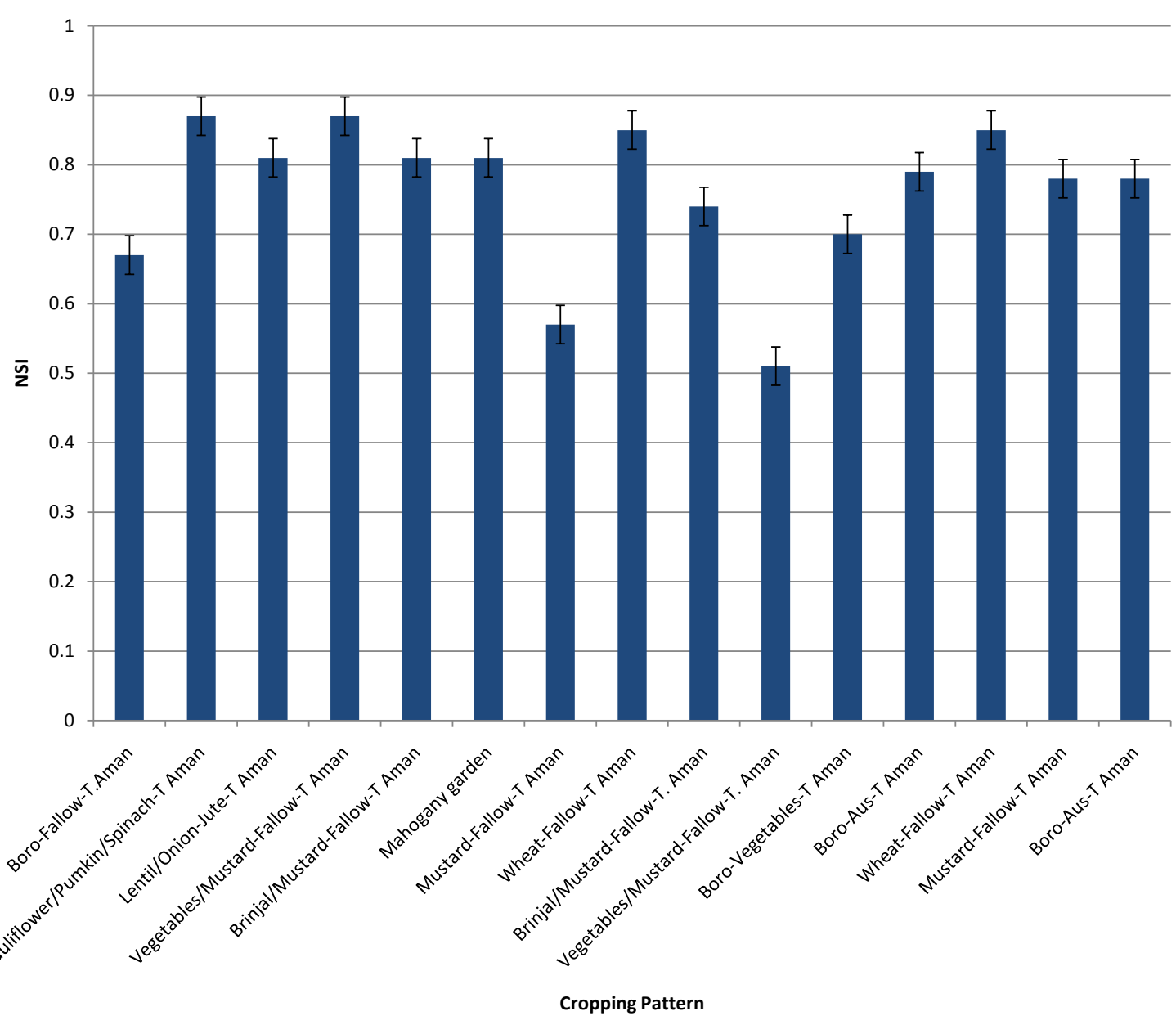

Figure 6. Normalized stability index of silt loam soils under different cropping patterns. 


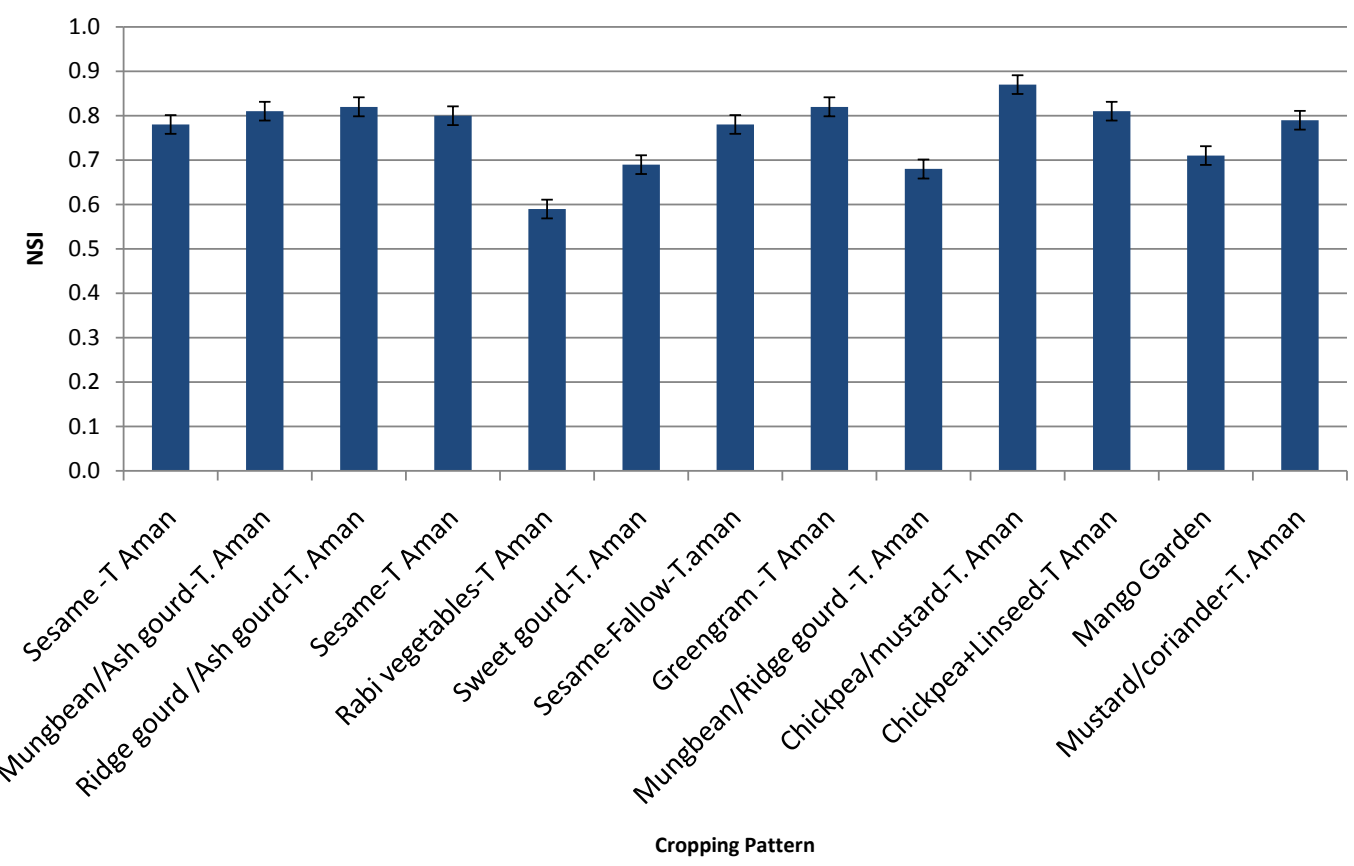

Figure 7. Normalized stability index of silty clay loam soils under different cropping patterns.

Normalized Stability Index of Silty Clay soils under different cropping patterns are presented in Figure 8. In Silty Clay soils the highest NSI value (0.89) obtained under Wheat-Fallow-T. Aman (Sample No 15) and the lowest value (0.61) obtained under Lentil-Fallow-T. Aman cropping pattern (Sample No 13). Rabbi et al. [12] reported that aggregate stability of soils of Ganges River and Tidal Floodplains of Khulna region increased with increasing clay percentage of soils.

The value of NSI can vary between 0 to 1 [15]. The lower NSI indicated that the aggregates were not water stable. Earlier investigation by Rabbi et al. [12] indicated that water stability of aggregates of silt loam texture was low. The mineralogy of soils may play important role in aggregate stability [15]. However, in the present study mineral identification was not done. In the present study the NSI increased with decreasing cropping intensity. Soils under Fallow-Fallow-T. Amon cropping pattern had higher NSI. The cultivation of rice in winter and monsoon season also decreased NSI of soils. Six et al. [25] reported that conventional tillage with high cropping intensity caused maximum destruction of soil. It has been reported that stable aggregate of tilled soils is lower than that of no-tilled soils [26] due to aggregate breakdown in tillage process.

The cultivation of rice twice a year accelerates the aggregate destruction rate. Adiku et al., [27] concluded that soils under rice base cultivation were more prone to degradation. The inclusion of shrimp in land use markedly decreased the NSI may be due to application of saline water in soil. Rabbi et al. [11] reported that shrimp culture can deteriorate the tilth of soil. Cropping patterns have pronounced effect on soil organic matter content and hence affect the tilth of soil. Soil structure plays a dominant role in controlling microbial access to organic substrates. The labile organic material may be physically protected from 


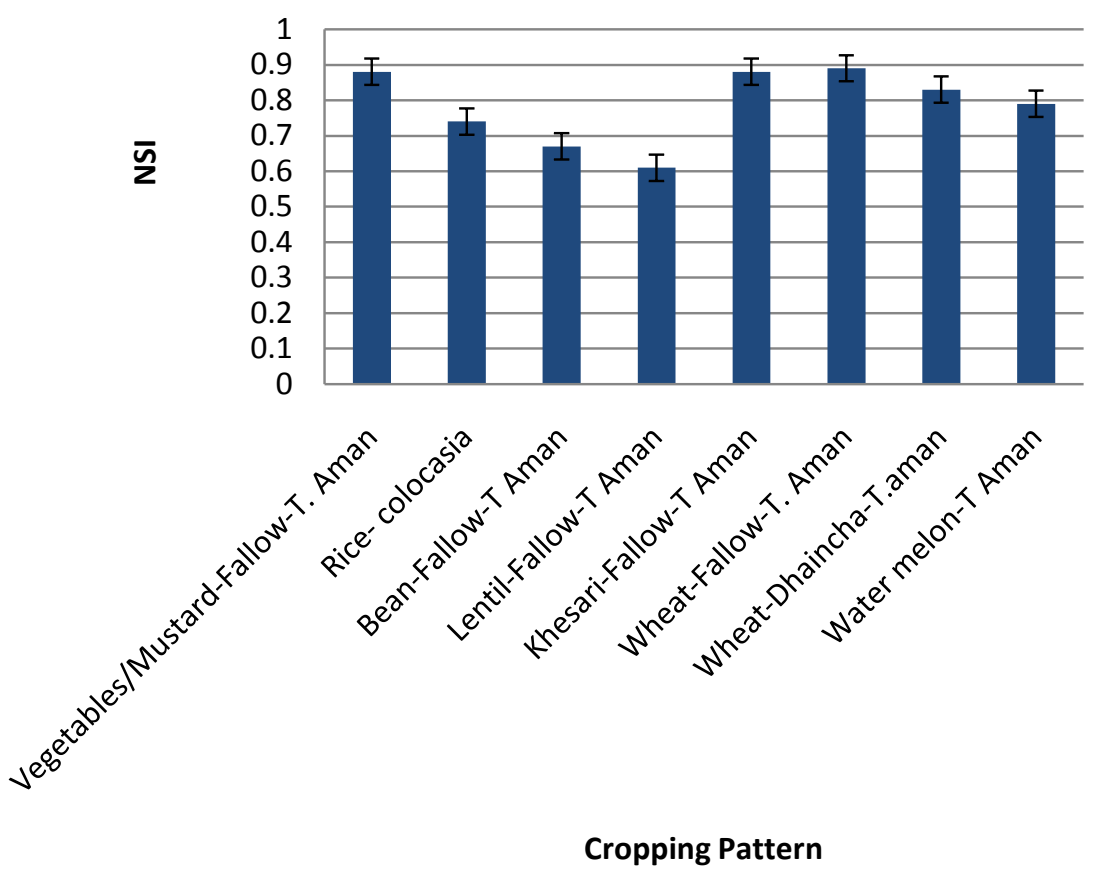

Figure 8. Normalized stability index of silty clay soils under different cropping patterns.

decomposition by its incorporation into soil aggregates [28]. Soil organic matter can be: 1) physically stabilized, or protected from decomposition, through micro aggregation, or 2) intimate association with silt and clay particles, and 3) can be biochemically stabilized through the formation of recalcitrant SOM compounds [5]. Hence, Soil aggregation is an important process of C sequestration [8].

\subsection{Soil Chemical Properties}

The $\mathrm{pH}$ of the soils under different cropping patterns varied from 5.99 to 7.85 (Table 3). The highest pH value was found in Ganges Meander Floodplain soils of Bahadurpur, Jessore (Sample No 9) under Vegetables/Mustard-Fallow-T. Aman cropping pattern and the lowest was found in soils of High Barind Tract under Chickpea + Linseed-T. Aman cropping pattern (Sample No 32).

The EC value of studied soils varied from 0.29 to $2.46 \mathrm{dS} \cdot \mathrm{m}^{-1}$ (Table 3). These results indicate that all the soils of the study area were non saline to slightly saline. The highest value of EC was obtained in soils of Ganges Tidal Floodplain under Bean-Fallow-T. Aman (Sample No 24) and lowest value of EC was obtained in soils of High Barind Tract under Rabi vegetables-T. Aman (Sample No 12).

\subsection{Analyses of Different Carbon Forms of Studied Soil}

\subsubsection{Active Carbon}

Active carbon of soil samples under different cropping patterns varied from 619.23 to $735.20 \mathrm{mg} \cdot \mathrm{kg}^{-1}$ with a mean value of $712.16 \mathrm{mg} \cdot \mathrm{kg}^{-1}$ (Appendix Table A1). The highest value was observed under Chickpea/mustard-T. Aman (Sample No 31) and the lowest value was found in case of Wheat-Fallow-T. Aman cropping 
Table 3. pH and EC of soil samples.

\begin{tabular}{|c|c|c|}
\hline Sample & $\mathrm{pH}$ & $\mathrm{EC}(\mathrm{dS} / \mathrm{m})$ \\
\hline 1 & 7.73 & 0.59 \\
\hline 2 & 7.80 & 0.40 \\
\hline 3 & 7.79 & 0.39 \\
\hline 4 & 7.51 & 0.33 \\
\hline 5 & 7.71 & 0.47 \\
\hline 6 & 7.53 & 0.37 \\
\hline 7 & 7.45 & 0.33 \\
\hline 8 & 7.62 & 0.37 \\
\hline 9 & 7.85 & 0.51 \\
\hline 10 & 6.70 & 0.32 \\
\hline 11 & 7.12 & 0.50 \\
\hline 12 & 6.53 & 0.29 \\
\hline 13 & 6.65 & 0.41 \\
\hline 14 & 7.60 & 0.58 \\
\hline 15 & 7.32 & 0.59 \\
\hline 16 & 7.39 & 0.70 \\
\hline 17 & 7.57 & 2.28 \\
\hline 18 & 7.26 & 2.17 \\
\hline 19 & 7.44 & 1.89 \\
\hline 20 & 6.98 & 1.55 \\
\hline 21 & 7.41 & 1.48 \\
\hline 22 & 7.14 & 2.14 \\
\hline 23 & 7.30 & 1.48 \\
\hline 24 & 7.25 & 2.46 \\
\hline 25 & 7.36 & 1.80 \\
\hline 26 & 7.19 & 1.89 \\
\hline 27 & 7.47 & 1.46 \\
\hline 28 & 7.67 & 1.43 \\
\hline 29 & 6.71 & 0.85 \\
\hline 30 & 6.67 & 0.61 \\
\hline 31 & 6.65 & 0.44 \\
\hline 32 & 5.99 & 0.44 \\
\hline 33 & 6.01 & 0.51 \\
\hline 34 & 6.10 & 0.54 \\
\hline 35 & 6.03 & 0.36 \\
\hline 36 & 6.48 & 0.63 \\
\hline
\end{tabular}


pattern (Sample No 30). Active carbon contents are presented in Figures 9-11 in Silt Loam, Silty Clay Loam and Silty Clay soils, respectively.

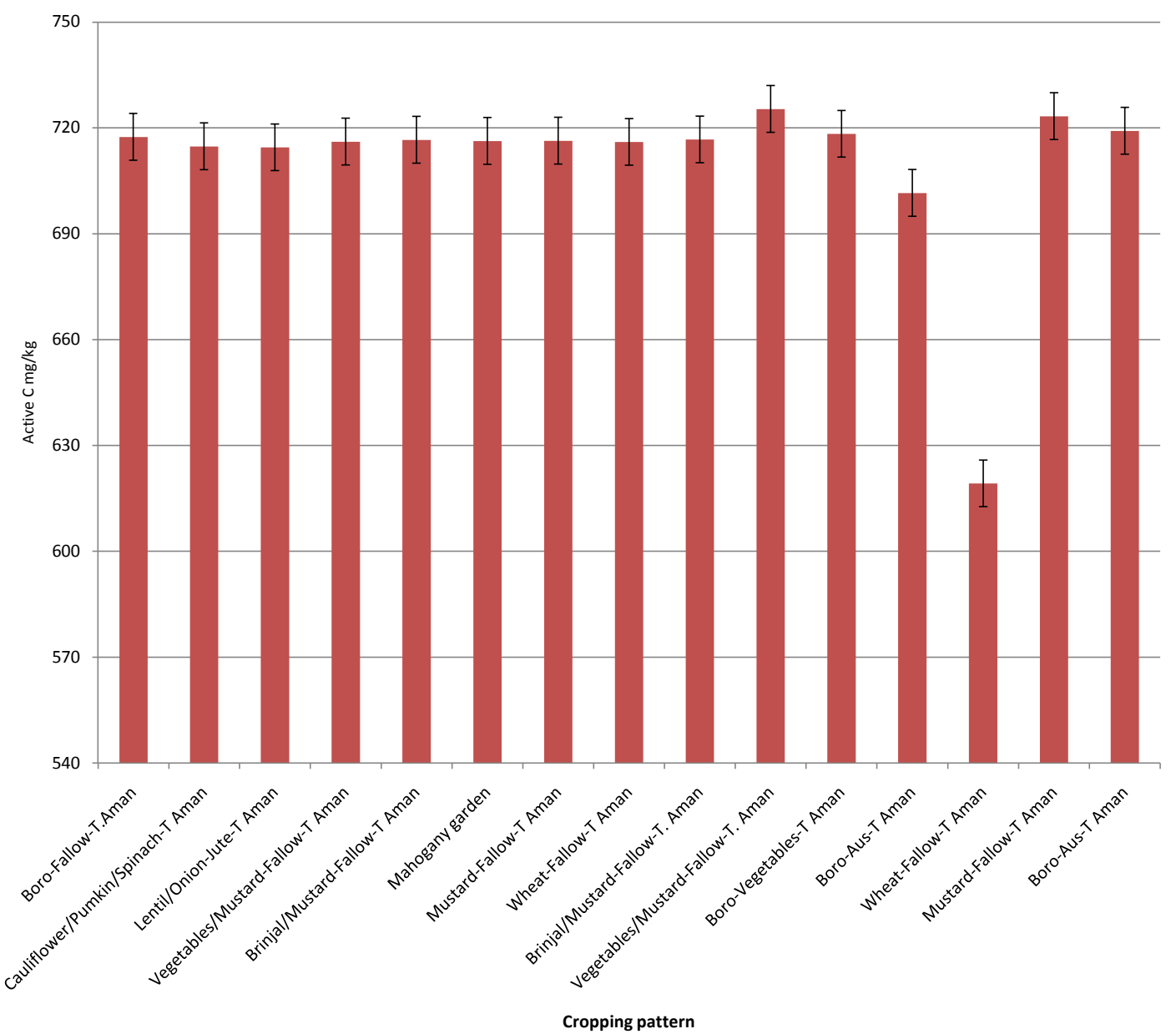

Figure 9. Active C (mg/kg) in Silt loam soils.
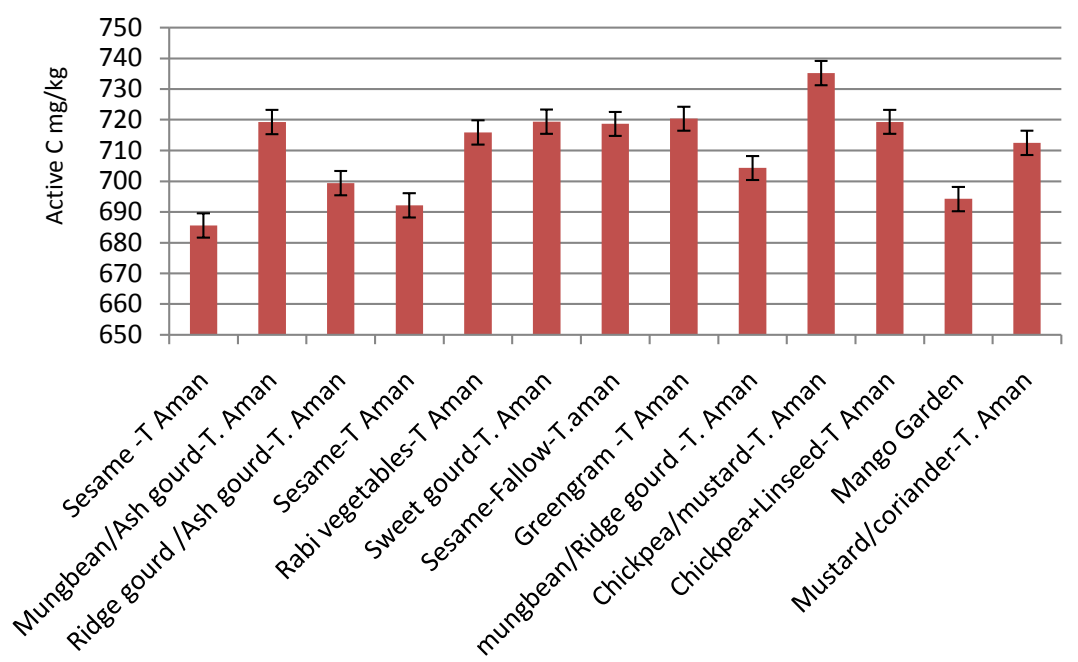

Cropping Pattern

Figure 10 . Active $\mathrm{C}(\mathrm{mg} / \mathrm{kg})$ in silty clay loam soils. 

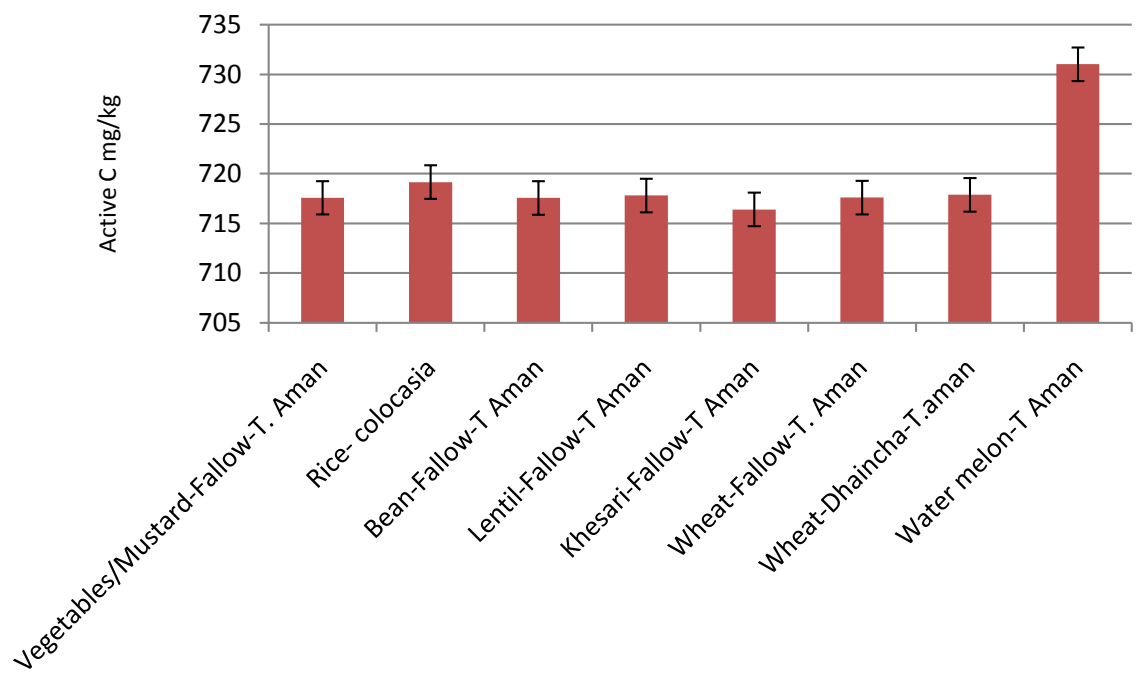

Cropping Pattern

Figure 11 . Active $\mathrm{C}(\mathrm{mg} / \mathrm{kg})$ in silty clay soils.

The active fraction of soil organic matter consists of materials with a relatively high average $\mathrm{C} / \mathrm{N}$ ratio (about 15 to 30 ) and short half-lives (half of these materials can be metabolized in a matter of a few months to a few years). Components include the living biomass, some of the fine particles of detritus (referred to as particulate organic matter, or POM), most of the polysaccharides, and other non humic substances, as well as some of the more labile (easily decomposed) fulvic acids. This active fraction provides most of the readily accessible food for the soil organisms and most of the readily mineralizable nitrogen. It is responsible for most of the beneficial effects on structural stability that lead to enhanced infiltration of water, resistance to erosion, and ease of tillage. The active fraction can be readily increased by the addition of fresh plant and animal residues, but it is also very readily lost when such additions are reduced or tillage is intensified. This fraction rarely comprises more than $10 \%$ to $20 \%$ of the total soil organic matter [29].

The content of soil organic carbon (SOC) can be affected by many factors, such as forest types [30], soil moisture, soil type, temperature and precipitation [31]. In our result, highest active carbon was under Chickpea/mustard/tomato-T. Aman. It may be the cause of addition of fresh plant and animal residues, soil moisture, soil type, soil organic carbon stock and organic carbon \%.

\subsubsection{Aggregate Associated Soil Organic Carbon (SOC)}

Soil organic carbon associated with different size aggregates were the highest (3.14\%) under Mungbean/Ash gourd-T. Aman (Sample No 20) and were the lowest $(0.36 \%)$ under Cauliflower/Pumkin/Spinach-T. Aman cropping pattern (Sample No 2). Aggregate associated SOC contents are presented in Figures 12-14 in Silt Loam, Silty Clay Loam and Silty Clay soils, respectively.

Organic carbon content in aggregate size ranges $>2000 \mu \mathrm{m}$ (SOC1), $2000-250$ $\mu \mathrm{m}$ (SOC2), 250 - $53 \mu \mathrm{m}$ (SOC3), and $<53 \mu \mathrm{m}$ (SOC4) varied from $0.36 \%-1.90 \%$, 


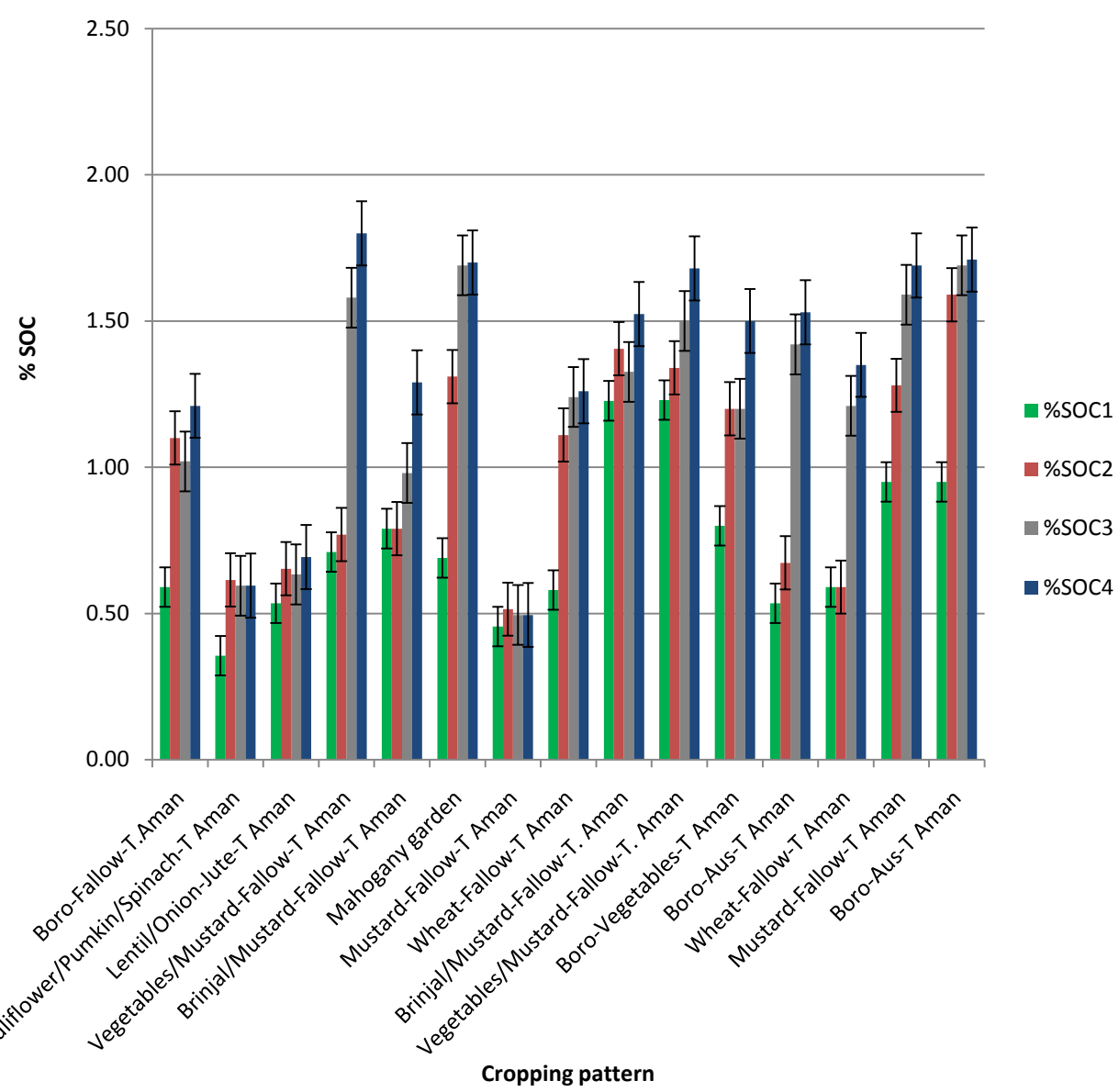

Figure 12. Aggregate associated C in silt loam soils under different patterns.

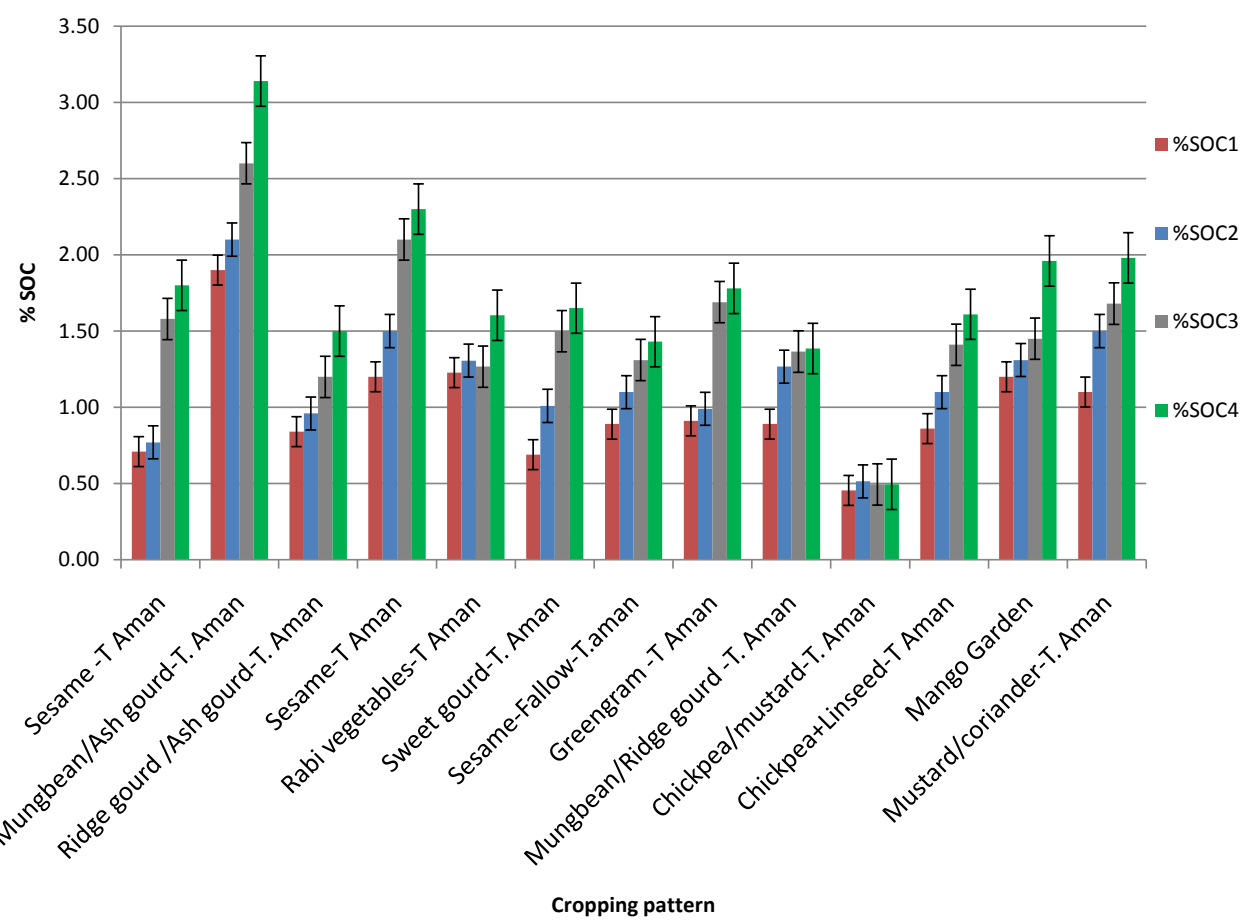

Figure 13. Aggregate associated C in silty clay loam soils under different patterns. 


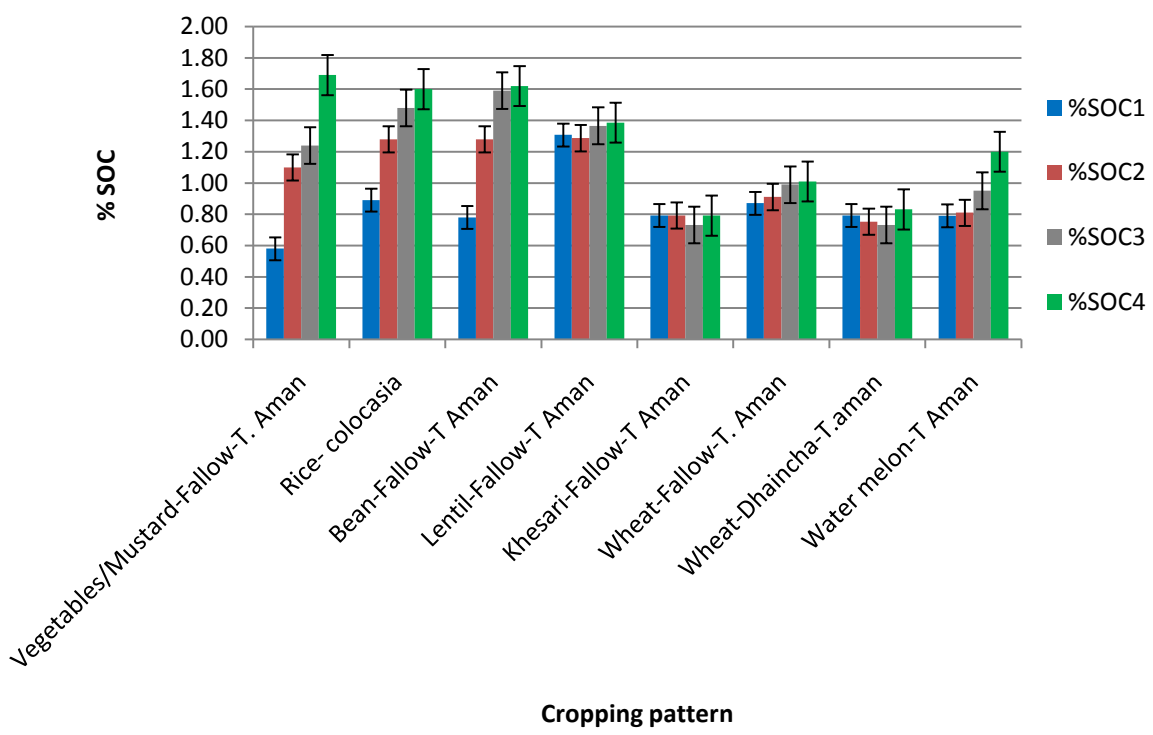

Figure 14. Aggregate associated C in silty clay soils under different patterns.

$0.52 \%-2.10 \%, 0.50 \%-2.60 \%$ and $0.50 \%-1.62 \%$, respectively (Appendix Table A2). The percentages of SOC associated with $<53 \mu \mathrm{m}$ aggregates were higher than those of $>2000 \mu \mathrm{m}, 2000-250 \mu \mathrm{m}$ and $250-53 \mu \mathrm{m}$, aggregates.

In Silt Loam soils (Figure 12), the highest SOC1 (1.23\%) was found in Vegetables/Mustard-Fallow-T. Aman cropping pattern (Sample No 17) and the lowest SOC1 (0.36\%) was found in Cauliflower/Pumkin/Spinach-T. Aman cropping pattern (Sample No 2). The highest SOC2 (1.59\%) was found in Boro-Aus-T. Aman cropping pattern (Sample No 34) and the lowest SOC2 (0.51\%) was found in Mustard-Fallow-T. Aman cropping pattern (Sample No 7). The highest SOC3 (1.69\%) was found in Mahogany garden and Boro-Aus-T. Aman cropping pattern (Sample No 6 and 34, respectively) and the lowest SOC3 (0.49\%) was found in Mustard-Fallow-T. Aman cropping pattern (Sample No 7). The highest SOC4 (1.69\%) was found in Mahogany garden and Boro-Aus-T. Aman cropping pattern (Sample No 6 and 34, respectively) and the lowest SOC4 (0.49\%) was found in Mustard-Fallow-T. Aman cropping pattern (Sample No 7).

In Silty Clay Loam soils (Figure 13), the highest SOC1 (1.90\%), SOC2 (2.10\%), SOC3 (2.60\%) and SOC4 (3.14\%) was found in Mungbean/Ash gourd-T. Aman cropping pattern (Sample No 20 ) and the lowest SOC1 (0.46\%), SOC2 (0.51\%), SOC3 $(0.49 \%)$ and SOC4 (0.49\%) was found in Chickpea/mustard-T. Aman cropping pattern (Sample No 31).

In Silty Clay soils (Figure 14), the highest SOC1 (1.31\%) and SOC2 (1.29\%) was found in Lentil-Fallow-T. Aman cropping pattern (Sample No 13) and the lowest SOC1 $(0.58 \%)$ was found in Vegetables/Mustard-Fallow-T. Aman cropping pattern (Sample No 9). The lowest SOC2 (0.75\%) was found in Wheat-Dhaincha-T. Aman cropping pattern (Sample No 16). The highest SOC3 (1.59\%) was found in Bean-Falow-T. Aman cropping pattern (Sample No 12) and the lowest SOC3 $(0.73 \%)$ was found in both Khesari-Fallow-T. Aman and Wheat-Dhaincha-T. 
Aman cropping pattern (Sample No 14 and 16 respectively). The highest SOC4 (1.69\%) was found in Vegetables/Mustard-Fallow-T. Aman cropping pattern (Sample No 9) and the lowest SOC4 (0.79\%) was found in Khesari-Fallow-T. Aman cropping pattern (Sample No 14).

High cropping intensity under conventional cultivation commonly has decrease in organic carbon content, because the amount of organic material returned to the soils is considerably lower and tillage enhance the decomposition of native soil organic matter [32]. Paddy soils with periodic submergence were slightly higher in organic carbon content than upland soils.

The average SOC associated with aggregates was in the order of SOC4 > SOC3 $>$ SOC2 $>$ SOC1. The fresh organic carbon that was derived from the crops were first incorporated to larger aggregates and then shunted to micro aggregates after decomposition by soil microbes and this process was stimulated by disturbance by conventional tillage [33]. The percentage of SOC associated with $2000-250 \mu \mathrm{m}, 250-53 \mu \mathrm{m}$ and $<53 \mu \mathrm{m}$ aggregates increased with increasing clay percentages of soils. Wiseman and Puttmann [34] described the importance of specific surface of clays rather than percentage of clays in SOC sorption. Wattel-Koekkoek et al. [35] showed that smectites have large sorptive capacity for SOC. The existing reports on clay minerals of Ganges River Floodplain of Bangladesh concluded that illite is the dominant clay mineral of this floodplain [36]. The surface area of illite is about $70-120 \mathrm{~m}^{2} \cdot \mathrm{g}^{-1}$. So, the capacity of illite to sorb SOC at may play an important role and it requires further research to conclude.

\subsubsection{Soil Organic Carbon Stock (SOC Stock)}

In order to estimate the potential of carbon sequestration in soils the original C stocks in soils need to be determined. Soil organic carbon stock of Silt Loam, Silty Clay Loam and Silty Clay soils under different cropping pattern ranged from 0.35 to $1.07 \mathrm{~kg} \mathrm{C} \mathrm{m}^{-2}, 0.42$ to $1.62 \mathrm{~kg} \mathrm{C} \mathrm{m}^{-2}, 0.48$ to $1.07 \mathrm{~kg} \mathrm{C} \mathrm{m}^{-2}$, respectively (Figures 15-17).

The highest organic carbon stock was found in Silty Clay Loam soil under Mungbean/Ash gourd-T. Aman cropping pattern (Sample no 4). The lowest SOC stock was found in Silt Loam soil under Cauliflower/Pumkin/Spinach-T. Aman Cropping pattern (Sample No 2).

Batjes [37] discussed the total soil C stock distribution by major ecological zones. Such zones show large differences in organic carbon storage, mainly in relation to temperature and rainfall. Soil $\mathrm{C}$ stocks down to $1 \mathrm{~m}$ depth range from about $4 \mathrm{~kg} \cdot \mathrm{m}^{-2}$ (in the arid zone) to $21-24 \mathrm{~kg} \cdot \mathrm{m}^{2}$ (in polar or boreal regions); with intermediate values of 8 to $10 \mathrm{~kg} \cdot \mathrm{m}^{-2}$ in tropical zones. But our value ranged from $1.07 \pm 0.01$ to $0.35 \pm 0.04 \mathrm{~kg} \mathrm{C} \mathrm{m}^{-2}$ (top soil). This lower range may be due to the erosion of top soil and intense cultivation. The contribution of the tropical regions to the global pool of soil carbon is $384-403 \mathrm{Pg} \mathrm{C}$ to $1 \mathrm{~m}$ and $616-640$ Pg C to $2 \mathrm{~m}$ depth [38], compared to about $1500 \mathrm{Pg} \mathrm{C}$ to $1 \mathrm{~m}$ for the world (2736 - 2456 Pg to $2 \mathrm{~m}$ depth). The arid zone, which covers 40 percent of the global land surface, stocks only 5 percent $(100 \mathrm{Pg})$ of the total. These agro-ecological 


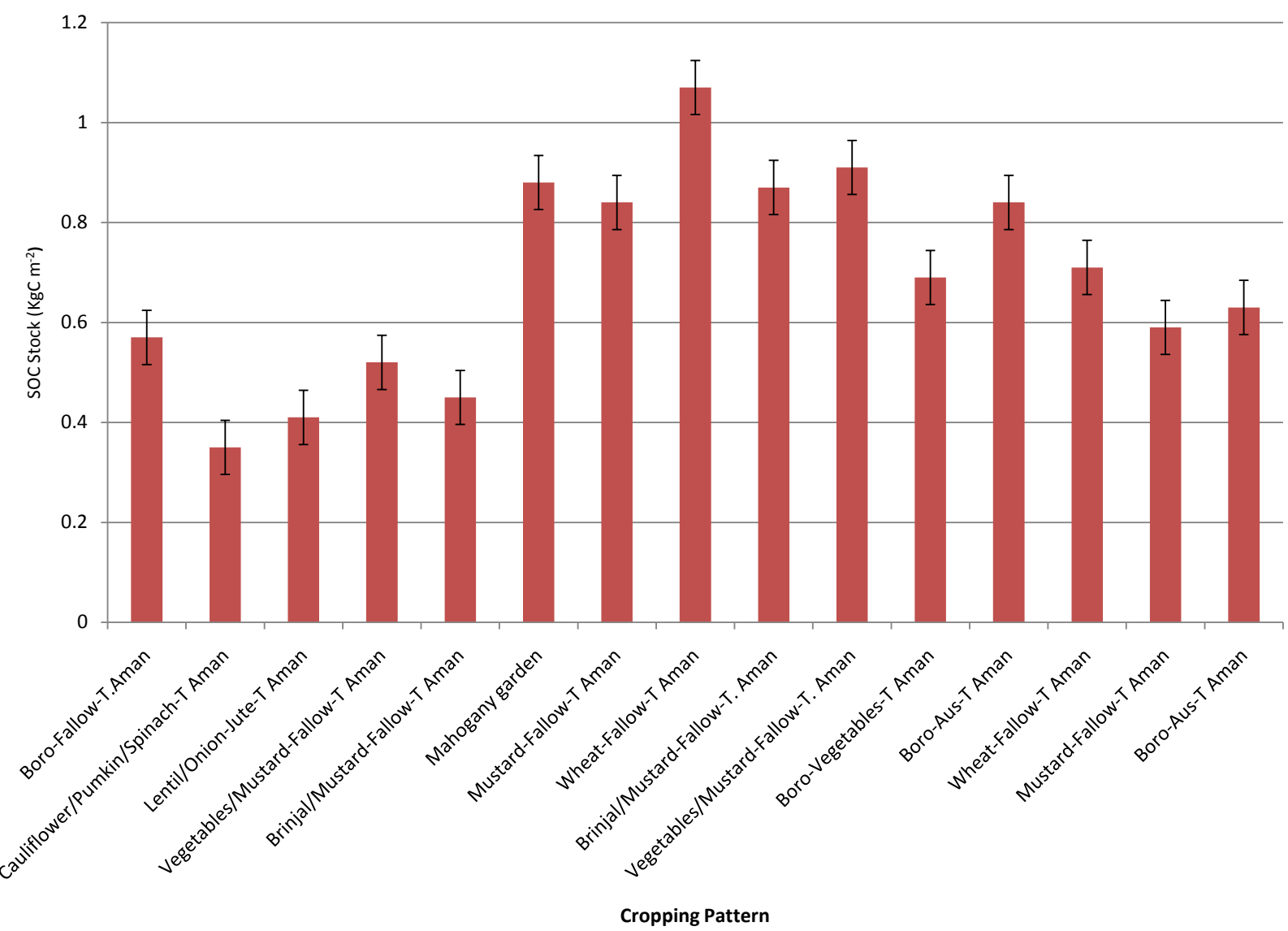

Figure 15. Soil organic carbon stock in silt loam soil.

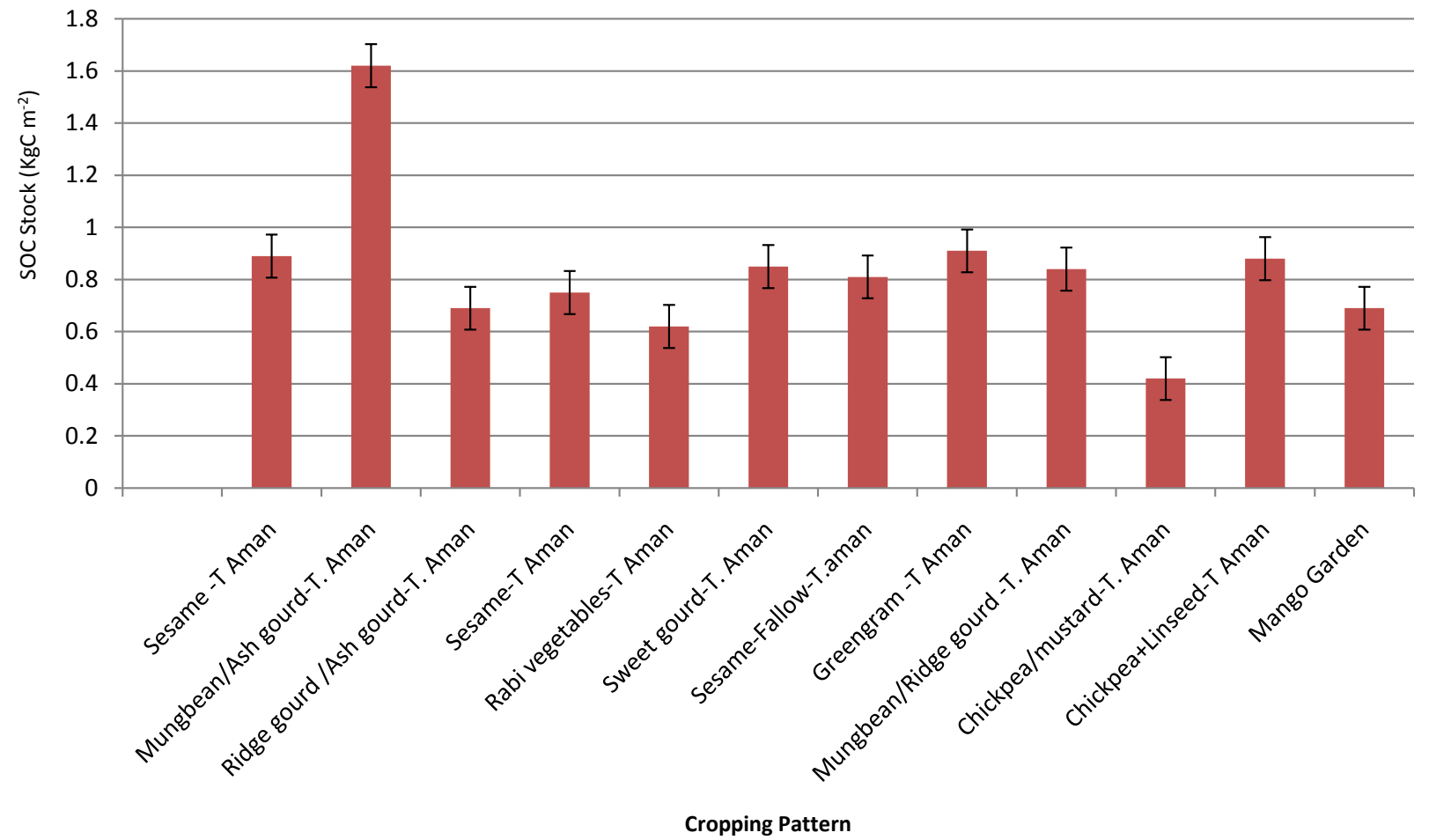

Figure 16. Soil organic carbon stock in silty clay loam soil. 

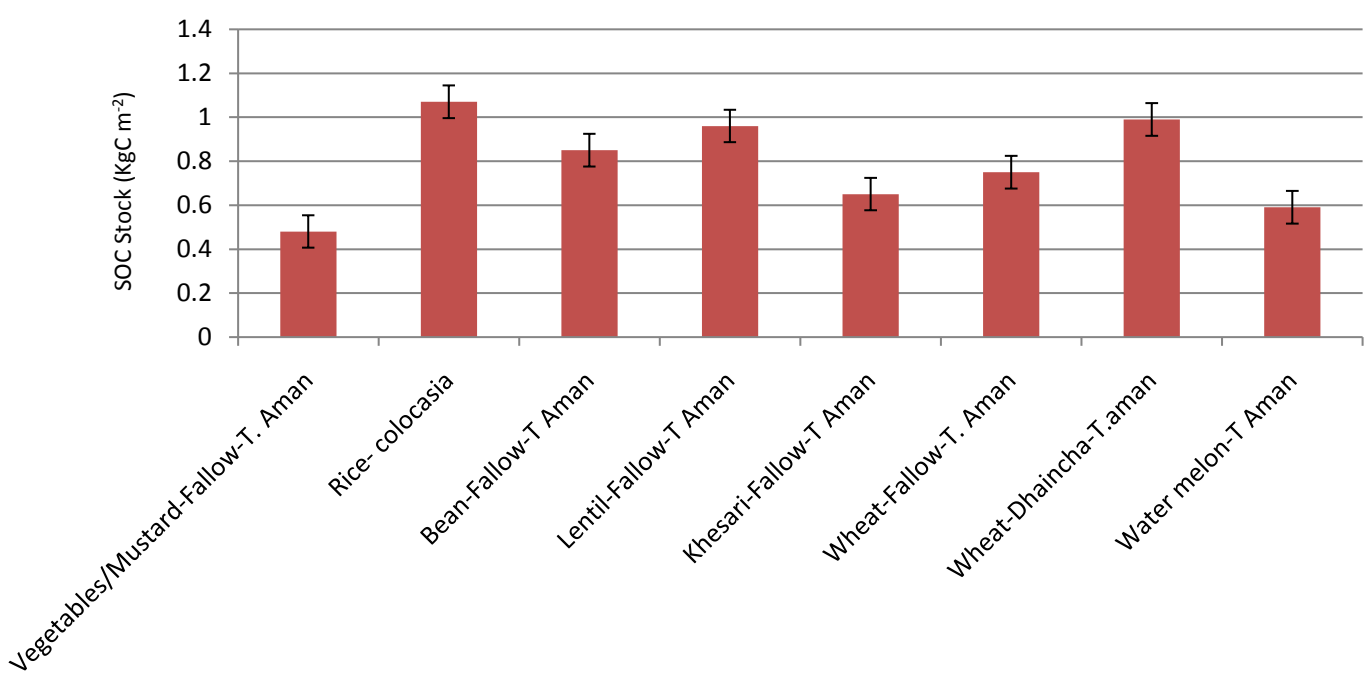

Cropping Pattern

Figure 17. Soil organic carbon stock in silty clay soil.

zones, developed by FAO, can constitute a reference framework to evaluate and monitor soil C storage in soils.

\subsection{Relationship among Soil Properties}

Significant positive correlations were found between SOC stock and SOC1, SOC stock and SOC2, SOC stock and SOC3, SOC stock and SOC4 (Appendix Table A3). The SOC content in all four size ranges under this study was positively correlated with each other.

\section{Conclusion}

The distribution of aggregate size classes was influenced by land cultivation, as tillage destroyed especially aggregates $>1000 \mu \mathrm{m}$. Average SOC stocks in the soils under investigation were in order of Silty Clay Loam $>$ Silty Clay $>$ Silt Loam. The average SOC associated with aggregates was in the order of SOC4 $>$ SOC3 $>$ SOC2 $>$ SOC1. The aggregate associated SOC concentration was greater for microaggregates $(<250 \mu \mathrm{m})$ than macroaggregates $(>250 \mu \mathrm{m})$ in the soils.

\section{Data Availability}

The data used to support findings of this study are available from the corresponding author upon request.

\section{Acknowledgements}

This study was made possible with funding from University Grants Commission of Bangladesh for climate change issue. The support rendered by Khulna University towards implemented of the study is acknowledged. We would like to express our sincere gratitude to our supervisor Associate Professor Md. Sadiqul Amin for his continuous supervision, guidance, inspiration and thoughtful sug- 
gestion during completion of the work. Individual efforts alone can never contribute in totally to a successful completion of any venture. We would be failing in our duty if we did not state our gratitude and appreciation to the following individuals who have made the valuable contribution towards the review work.

\section{Conflicts of Interest}

The authors declare that there is no conflict of interest regarding authorship and publication of this paper.

\section{References}

[1] Lal, R. (2004) Soil Carbon Sequestration Impacts on Global Climate Change and Food Security. Science, 304, 1623-1627. https://doi.org/10.1126/science.1097396

[2] Sholes, B. (1999) Will the Terrestrial Carbon Sink Saturate Soon? IGPB Newsletter, 37, 2-3.

[3] Anandacoomaraswamy, A., Ekanayake, S.A.B., Ananthacumaraswamy, S., Chishom, A.H., Jayasuriya, S. and Flanagan, D.C. (2001) Effect of Land Degradation on Tea Productivity in Sri Lanka. Proceedings of the Intl. Symposium, Honolulu, Hawaii, 3-5 January 2001, 75-78.

[4] Rice, C.W. and Angle, J.S. (2004) Applications of Biotechnology to Mitigation of Greenhouse Warming: A Role for Genetically Modified Organisms in Soil Carbon Sequestration. Proceeding of the St. Michael s II Workshop, April 2003, 61-78.

[5] Six, J., Feller, C., Denef, K., Ogle, S.M., De Moraes Sa, J.C. and Albrecht, A. (2002) Soil Organic Matter, Biota and Aggregation in Temperate and Tropical Soils-Effects of No-Tillage. Agronomie, 22, 755-775.https://doi.org/10.1051/agro:2002043

[6] Tisdall, J.M. and Oades, J.M. (1982) Organic Matter and Water-Stable Aggregates in Soils. Journal of Soil Science, 33, 141-163. https://doi.org/10.1111/j.1365-2389.1982.tb01755.x

[7] Lal, R., Kimble, J., Follet, R. and Cole, C.V. (1998) The Potential of US Cropland to Sequester Carbon and Mitigate the Greenhouse Effect. Sleeping Bear Press Inc., Ann Arbor, MI.

[8] Shrestha, B.M., Singh, B.R., Sitaula, B.K., Lal, R. and Bajracharya, R.M. (2007) Soil Aggregate- and Particle-Associated Organic Carbon under Different Land Uses in Nepal. Soil Science Society of America Journal, 71, 1194-1203. https://doi.org/10.2136/sssaj2006.0405

[9] Feller, C. and Beare, M.H. (1997) Physical Control of Soil Organic Matter Dynamics in the Tropics. Geoderma, 79, 69-116. https://doi.org/10.1016/S0016-7061(97)00039-6

[10] Holeplass, H., Singh, B.R. and Lal, R. (2004) Carbon Sequestration in Soil Aggregates under Different Crop Rotations and Nitrogen Fertilization in an Inceptisol in Southeastern Norway. Nutrient Cycling in Agroecosystems, Norway, 70, 167-177. https://doi.org/10.1023/B:FRES.0000048483.94397.b6

[11] Rabbi, S.M.F., Bhuiyan, M.R. and Amin, M.S. (2007) Evaluation of Tilth Index of Soils under Different Cropping Patterns. Final Project Report, University Grants Commission, Dhaka.

[12] Rabbi, S.M.F., Rahman, A. and Kibria, K.Q. (2004) Aggregate Stability of Ganges Tidal Floodplain Soils and Its Relationship with Soil Physical and Chemical Properties. Bangladesh Journal of Soil Science, 30, 61-69. 
[13] Gee, G.W. and Bauder, J.W. (1986) Particle Size Analysis. In: Klute, A., Ed., Methods of Soil Analysis. Part 1 Physical and Mineralogical Methods, 2nd Edition, American Society of Agronomy, Inc., Madison, 383-411. https://doi.org/10.2136/sssabookser5.1.2ed.c15

[14] Blake, G.R. and Hartge, K.H. (1986) Bulk Density and Particle Density. In: Klute, A., Ed., Methods of Soil Analysis, Part 1-Physical and Mineralogical Methods, 2nd Edition, American Society of Agronomy-Soil Science Society of America, Madison, 363-382.

[15] Six, J., Elliott, E.T., and Paustian, K. (2000) Soil Macroaggregate Turnover and Microaggregate Formation: A Mechanism for C Sequestration under No-Tillage Agriculture. Soil Biology and Biochemistry, 32, 2099-2103. https://doi.org/10.1016/S0038-0717(00)00179-6

[16] Jackson, M.L. (1973) Soil Chemical Analysis. Prentice Hall of India Pvt. Ltd., New Delhi.

[17] USDA (2004) Soil Survey Laboratory Manual. Soil Survey Investigation Report No. 42, Version 4. USDA. NRCS, Nebraska, USDA.

[18] Ellert, B.H., Janzen, H.H., VandenBygaart, A.J. and Bremer, E. (2008) Measuring Change in Soil Organic Carbon Storage. In: Carter M.R. and Gregorich, E.G., Eds., Soil Sampling and Methods of Analysis, 2nd Edition, CRC Press, Boca Raton, A321-A352.

[19] Weil, R.R., Kandikar, R.I., Stine, M.A., Gruver, J.B. and Samson-Liebig, S.E. (2003) Estimating Active Carbon for Soil Quality Assessment: A Simplified Method for Laboratory and Field Use. American Journal of Alternative Agriculture, 18, 3-17. https://doi.org/10.1079/AJAA2003003

[20] Gomez, K.A. and Gomez, A.A. (1984) Statistical Procedures for Agricultural Research. 2nd Edition, International Rice Research Institute, Los Banos, 627.

[21] Soil Resources Development Institute (1965-1986) Reconnaissance Soil Survey Reports of Bangladesh, Soil Resources and Development Institute, Farmgate.

[22] Joshua, W.D. and Rahman, M. (1983) Physical Properties of Soils in the Ganges River Floodplain of Bangladesh. SRDI, Dhaka.

[23] Weil. R.R. and Kroontje, W. (1979) Physical Condition of a Davidson Clay Loam after Five Years of Heavy Poultry Manure Applications. Journal of Environmental Quality, 8, 387-392. https://doi.org/10.2134/jeq1979.00472425000800030024x

[24] Franzluebbers, A.J., Stuedemann, J.A. and Wilkinson, S.R. (2001) Bermuda Grass Management in the Southern Piedmont of the USA: I. Soil and Surface Residue Carbon and Sulfur. Soil Science Society of America Journal, 65, 8334-8341. https://doi.org/10.2136/sssaj2001.653834x

[25] Six, J., Elliott, E.T. and Paustian, K. (1999) Aggregate and Soil Organic Matter Dynamics under Conventional and Non-Tillage Systems. Soil Science Society of America Journal, 63, 1350-1358. https://doi.org/10.2136/sssaj1999.6351350x

[26] Pagliai, M., Vignozzi, N. and Pellegrini, S. (2004) Soil Structure and the Effect of Management Practices. Soil and Tillage Research, 79, 131-143. https://doi.org/10.1016/j.still.2004.07.002

[27] Adiku, S.G.K., Narh, S., Jones, J.W., Laryea, K.B. and Dowuona, G.N. (2008) Short-Term Effects of Crop Rotation, Residue Management, and Soil Water on Carbon Mineralization in a Tropical Cropping System. Plant and Soil, 311, 29-38. https://doi.org/10.1007/s11104-008-9652-y

[28] Gregorich, E.G., Kachanoski, R.G. and Voroney, R.P. (1989) Carbon Mineralization 
in Soil Size Fractions after Various Amounts of Aggregate Disruption. Journal Soil Science, 40, 649-659. https://doi.org/10.1111/j.1365-2389.1989.tb01306.x

[29] Brady, N.C. and Weil, R.R. (2002) The Nature and Properties of Soils. 13th Edition, Pearson Education Pvt. Ltd., Singapore, 128-540.

[30] Deng, X.W., Han, S.J., Hu, Y.L. and Zhou, Y.M. (2009) Carbon and Nitrogen Transformations in Surface Soils under Ermans birch and Dark Coniferous Forests. Pedosphere, 19, 230-237. https://doi.org/10.1016/S1002-0160(09)60112-0

[31] Jobbagy, E.G. and Jackson, R.B. (2000) The Vertical Distribution of Soil Organic Carbon and Its Relation to Climate and Vegetation. Ecological Applications, 10, 423-436. https://doi.org/10.1890/1051-0761(2000)010[0423:TVDOSO]2.0.CO;2

[32] Dalal, R.C and Bridge, B.J. (1996) Aggregation and Organic Matter Storage in Sub-Humid and Semi-Arid Soils. In: Carter, M.R. and Stewart, B.A., Eds., Structure and Organic Matter Storage in Agricultural Soils, CRC Press, Boca Raton, 263-307.

[33] Franzluebbers, A.J. and Arshad, M.A. (1997) Soil Microbial Biomass and Mineralizable Carbon of Water-Stable Aggregaes. Soil Science Society of America Journal, 61, 1090-1097. https://doi.org/10.2136/sssaj1997.03615995006100040015x

[34] Wiseman, C.L.S. and Puttman, W. (2005) Soil Organic Carbon and Its Sorptive Preservation in Central Germany. European Journal of Soil Science, 56, 65-76. https://doi.org/10.1111/j.1351-0754.2004.00655.x

[35] Wattel-Koekkoek, E.J.W., Van Genuchten, P.P.L., Buurman, P. and Van Lagen, B. (2003) Amount and Composition of Clay-Associated Soil Organic Matter in a Range of Kaolinitic and Smectitic Soils. Geoderma, 99, 27-49. https://doi.org/10.1016/S0016-7061(00)00062-8

[36] Ahmed, I.U., Akhter, S. and Ahsan, M. (2004) Mineralogical Characterization of Clay Fraction of Some Ganges Floodplain Soils. Bangladesh Journal of Soil Science, 30, 71-78.

[37] Batjes, N.H. (1999) Management Options for Reducing $\mathrm{CO}_{2}$ Concentrations in the Atmosphere by Increasing Carbon Sequestration in the Soil. ISRIC, Wageningen, 114.

[38] Batjes, N.H. (1996) Total Carbon and Nitrogen in the Soils of the World. European Journal of Soil Science, 47, 151-163. https://doi.org/10.1111/j.1365-2389.1996.tb01386.x 


\section{Appendix}

Table A1. Descriptive statistics: bulk density, particle density, porosity, sand, silt, clay, NSI, pH, EC, OC, SOC1, SOC2, SOC3, SOC4, SOC stock and active carbon.

\begin{tabular}{|c|c|c|c|c|}
\hline Variable & Mean & St Dev & Minimum & Maximum \\
\hline Bulk density (g/cc) & 1.41 & 0.1503 & 1.18 & 1.84 \\
\hline Particle Density (g/cc) & 2.49 & 0.0352 & 2.44 & 2.59 \\
\hline Porosity \% & 43.518 & 5.959 & 25.88 & 52.980 \\
\hline \%Sand & 15.378 & 5.079 & 7 & 23 \\
\hline \%Silt & 55.14 & 6.51 & 40 & 68 \\
\hline$\%$ Clay & 29.51 & 8.13 & 15 & 48 \\
\hline NSI & 0.7681 & 0.0942 & 0.51 & 0.89 \\
\hline $\mathrm{pH}$ & 7.14 & 0.5509 & 5.99 & 7.85 \\
\hline $\mathrm{EC}(\mathrm{dS} / \mathrm{m})$ & 0.932 & 0.688 & 0.29 & 2.46 \\
\hline Active C (mg.kg $\left.{ }^{-1}\right)$ & 712.16 & 18.51 & 619.23 & 735.20 \\
\hline$\% \mathrm{SOC} 1$ & 0.8500 & 0.2995 & 0.3552 & 1.90 \\
\hline$\% \mathrm{SOC} 2$ & 1.0751 & 0.3437 & 0.5146 & 2.10 \\
\hline$\%$ SOC3 & 1.3040 & 0.4329 & 0.4948 & 2.60 \\
\hline$\% \mathrm{SOC} 4$ & 1.4697 & 0.5076 & 0.4948 & 3.14 \\
\hline SOC Stock $\left(\mathrm{Kg} \mathrm{C} \mathrm{m}^{-2}\right)$ & 0.7681 & 0.2357 & 0.3500 & 1.62 \\
\hline
\end{tabular}

Table A2. Normalized stability index and different carbon forms.

\begin{tabular}{|c|c|c|c|c|c|c|c|}
\hline Sample No & NSI & Active $\mathrm{C} \mathrm{mg/kg}$ & $\begin{array}{l}\text { SOC Stock } \\
\left(\mathrm{Kg} \mathrm{C} \mathrm{m}^{-2}\right)\end{array}$ & $\%$ SOC1 & $\% \mathrm{SOC} 2$ & $\%$ SOC3 & $\%$ SOC4 \\
\hline 1 & 0.67 & 717.41 & 0.57 & 0.59 & 1.10 & 1.02 & 1.21 \\
\hline 2 & 0.87 & 714.72 & 0.35 & 0.36 & 0.61 & 0.59 & 0.59 \\
\hline 3 & 0.81 & 714.45 & 0.41 & 0.53 & 0.65 & 0.63 & 0.69 \\
\hline 4 & 0.87 & 716.06 & 0.52 & 0.71 & 0.77 & 1.58 & 1.80 \\
\hline 5 & 0.81 & 716.57 & 0.45 & 0.79 & 0.79 & 0.98 & 1.29 \\
\hline 6 & 0.81 & 716.25 & 0.88 & 0.69 & 1.31 & 1.69 & 1.70 \\
\hline 7 & 0.57 & 716.33 & 0.84 & 0.46 & 0.51 & 0.49 & 0.49 \\
\hline 8 & 0.85 & 715.97 & 1.07 & 0.58 & 1.11 & 1.24 & 1.26 \\
\hline 9 & 0.88 & 717.58 & 0.48 & 0.58 & 1.10 & 1.24 & 1.69 \\
\hline 10 & 0.74 & 716.68 & 0.87 & 1.23 & 1.41 & 1.33 & 1.52 \\
\hline 11 & 0.74 & 719.15 & 1.07 & 0.89 & 1.28 & 1.48 & 1.60 \\
\hline 12 & 0.67 & 717.56 & 0.85 & 0.78 & 1.28 & 1.59 & 1.62 \\
\hline 13 & 0.61 & 717.81 & 0.96 & 1.31 & 1.29 & 1.37 & 1.39 \\
\hline 14 & 0.88 & 716.40 & 0.65 & 0.79 & 0.79 & 0.73 & 0.79 \\
\hline 15 & 0.89 & 717.60 & 0.75 & 0.87 & 0.91 & 0.99 & 1.01 \\
\hline 16 & 0.83 & 717.88 & 0.99 & 0.79 & 0.75 & 0.73 & 0.83 \\
\hline 17 & 0.51 & 725.32 & 0.91 & 1.23 & 1.34 & 1.50 & 1.68 \\
\hline 18 & 0.78 & 685.62 & 0.89 & 0.71 & 0.77 & 1.58 & 1.80 \\
\hline
\end{tabular}




\section{Continued}

\begin{tabular}{llllllll}
\hline 19 & 0.70 & 718.28 & 0.69 & 0.80 & 1.20 & 1.20 & 1.50 \\
20 & 0.81 & 719.26 & 1.62 & 1.90 & 2.10 & 2.60 & 3.14 \\
21 & 0.82 & 699.36 & 0.69 & 0.84 & 0.96 & 1.20 & 1.50 \\
22 & 0.80 & 692.18 & 0.75 & 1.20 & 1.50 & 2.10 & 2.30 \\
23 & 0.79 & 731.02 & 0.59 & 0.79 & 0.81 & 0.95 & 1.20 \\
24 & 0.59 & 715.85 & 0.62 & 1.23 & 1.31 & 1.27 & 1.60 \\
25 & 0.69 & 719.36 & 0.85 & 0.69 & 1.01 & 1.50 & 1.65 \\
26 & 0.78 & 718.66 & 0.81 & 0.89 & 1.10 & 1.31 & 1.43 \\
27 & 0.82 & 720.36 & 0.91 & 0.91 & 0.99 & 1.69 & 1.78 \\
28 & 0.68 & 704.32 & 0.84 & 0.89 & 1.27 & 1.37 & 1.39 \\
29 & 0.79 & 701.52 & 0.84 & 0.53 & 0.67 & 1.42 & 1.53 \\
30 & 0.85 & 619.23 & 0.71 & 0.59 & 0.59 & 1.21 & 1.35 \\
31 & 0.87 & 735.20 & 0.42 & 0.46 & 0.51 & 0.49 & 0.49 \\
32 & 0.81 & 719.32 & 0.88 & 0.86 & 1.10 & 1.41 & 1.61 \\
33 & 0.78 & 723.30 & 0.59 & 0.95 & 1.28 & 1.59 & 1.69 \\
34 & 0.78 & 719.13 & 0.63 & 0.95 & 1.59 & 1.69 & 1.71 \\
35 & 0.71 & 694.25 & 0.69 & 1.20 & 1.31 & 1.45 & 1.96 \\
36 & 0.79 & 712.50 & 0.94 & 1.10 & 1.50 & 1.68 & 1.98 \\
\hline
\end{tabular}

Table A3. Correlations among selected soil properties.

\begin{tabular}{ccccccccccc}
\hline & Db & PD & NSI & \%Silt & \%Clay Active C SOC Stock $\%$ SOC1 \%SOC2 \%SOC3 \\
\hline PD & 0.170 & & & & & & & & \\
& 0.320 & & & & & & & & \\
NSI & 0.113 & -0.384 & & & & & & & \\
& 0.510 & 0.021 & & & & & & & \\
\%Silt & -0.144 & 0.458 & -0.263 & & & & & & \\
& 0.401 & 0.005 & 0.122 & & & & & & \\
\%Clay & 0.100 & -0.197 & 0.094 & -0.793 & & & & & \\
& 0.564 & 0.249 & 0.586 & 0.000 & & & & & \\
Active C & -0.043 & -0.159 & -0.133 & -0.104 & 0.133 & & & & \\
& 0.805 & 0.356 & 0.438 & 0.545 & 0.439 & & & & \\
SOC Stoc & 0.175 & 0.075 & -0.198 & -0.180 & 0.256 & -0.007 & & & \\
& 0.309 & 0.662 & 0.247 & 0.295 & 0.131 & 0.967 & & & & \\
\%SOC1 & 0.004 & 0.004 & -0.300 & 0.035 & 0.170 & 0.088 & 0.591 & & & \\
& 0.980 & 0.982 & 0.076 & 0.841 & 0.321 & 0.608 & 0.000 & & & \\
\%SOC2 & 0.089 & -0.009 & -0.277 & -0.040 & 0.161 & 0.175 & 0.561 & 0.824 & & \\
& 0.607 & 0.961 & 0.101 & 0.818 & 0.347 & 0.308 & 0.000 & 0.000 & & \\
\%SOC3 & 0.214 & 0.159 & -0.083 & 0.031 & 0.124 & -0.112 & 0.604 & 0.685 & 0.797 & \\
& 0.210 & 0.354 & 0.631 & 0.858 & 0.473 & 0.516 & 0.000 & 0.000 & 0.000 & \\
& 0.101 & 0.133 & -0.075 & 0.032 & 0.172 & -0.124 & 0.555 & 0.725 & 0.792 & 0.966 \\
& 0.557 & 0.438 & 0.663 & 0.854 & 0.317 & 0.470 & 0.000 & 0.000 & 0.000 & 0.000 \\
\hline
\end{tabular}

Cell Contents: Pearson correlation; P-Value. 